\title{
Historicizing Roma in Central Europe
}

In Central Europe, limited success in revisiting the role of science in the segregation of Roma reverberates with the yet-unmet call for contextualizing the impact of ideas on everyday racism. This book attempts to interpret such a gap as a case of epistemic injustice. It underscores the historical role of ideas in race making and provides analytical lenses for exploring cross-border transfers of whiteness in Central Europe. In the case of Roma, the scientific argument in favor of segregation continues to play an outstanding role due to a long-term focus on the limited educability of Roma. The authors trace the long-term interrelation between racializing Roma and the adaptation by Central European scholars of theories legitimizing segregation against those considered non-white, conceived as unable to become educated or "civilized." Along with legitimizing segregation, sterilization and even extermination, theorizing ineducability has laid the groundwork for negating the capacity of Roma as subjects of knowledge. Such negation has hindered practices of identity and quite literally prevented Roma in Central Europe from becoming who they are. This systematic epistemic injustice still echoes in contemporary attempts to historicize Roma in Central Europe. The authors critically investigate contemporary approaches to historicize Roma as reproducing whiteness and inevitably leading to various forms of epistemic injustice. The methodological approach herein conceptualizes critical whiteness as a practice of epistemic justice targeted at providing a sustainable platform for reflecting upon the impact of the past on the contemporary situation of Roma.

Victoria Shmidt is Senior Researcher at the University of Graz in Austria. Her main interest is to deepen the approaches toward race science and racial thinking as agents and structures of nation-building in Central Eastern European countries.

Bernadette Nadya Jaworsky is Associate Professor of sociology at Masaryk University in the Czech Republic. Her current research focuses on media coverage of refugees, border narratives and the migration-populism nexus. 


\title{
Routledge Histories of Central and Eastern Europe
}

\section{Hungary since 1945}

Árpád von Klimó, translated by Kevin McAleer

\section{Romania under Communism}

Denis Deletant

\section{Bulgaria under Communism}

Ivaylo Znepolski, Mihail Gruev, Momtchil Metodiev, Martin Ivanov, Daniel Vatchkov, Ivan Elenkov, Plamen Doynow

\section{From Revolution to Uncertainty}

The Year 1990 in Central and Eastern Europe

Edited by Joachim von Puttkamer, Włodzimierz Borodziej,

and Stanislav Holubec

\section{Identities In-Between in East-Central Europe}

Edited by Jan Fellerer, Robert Pyrah and Marius Turda

\section{Communism, Science and the University}

Towards a Theory of Detotalitarianisation

Edited by Ivaylo Znepolski

\begin{abstract}
A Nation Divided by History and Memory
Hungary in the Twentieth Century and Beyond

Gábor Gyáni
\end{abstract}

\section{Historicizing Roma in Central Europe}

Between Critical Whiteness and Epistemic Injustice

Victoria Shmidt and Bernadette Nadya Jaworsky

www.routledge.com/Routledge-Histories-of-Central-and-Eastern-Europe/ book-series/CEE 


\section{Historicizing Roma in Central Europe}

Between Critical Whiteness

and Epistemic Injustice

\section{Victoria Shmidt and}

Bernadette Nadya Jaworsky

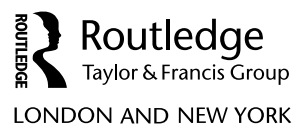


First published 2021

by Routledge

2 Park Square, Milton Park, Abingdon, Oxon OX14 4RN

and by Routledge

52 Vanderbilt Avenue, New York, NY 10017

Routledge is an imprint of the Taylor \& Francis Group, an informa business

(C) 2021 Victoria Shmidt and Bernadette Nadya Jaworsky

The right of Victoria Shmidt and Bernadette Nadya Jaworsky to be identified as authors of this work has been asserted by them in accordance with sections 77 and 78 of the Copyright, Designs and Patents Act 1988.

All rights reserved. No part of this book may be reprinted or reproduced or utilised in any form or by any electronic, mechanical, or other means, now known or hereafter invented, including photocopying and recording, or in any information storage or retrieval system, without permission in writing from the publishers.

Trademark notice: Product or corporate names may be trademarks or registered trademarks, and are used only for identification and explanation without intent to infringe.

British Library Cataloguing-in-Publication Data A catalogue record for this book is available from the British Library

Library of Congress Cataloging-in-Publication Data

A catalog record for this book has been requested

ISBN: 978-0-367-47198-9 (hbk)

ISBN: 978-1-003-03409-4 (ebk)

Typeset in Times New Roman

by Apex CoVantage, LLC 


\section{Contents}

List of Figures viii

Acknowledgments $\quad$ ix

List of Abbreviations $\quad x$

Introduction: a longue durée of segregation against Roma:

inside of whiteness

Critical whiteness as the only option for epistemic justice for

Roma in Central Europe: methodological grounds 4

Remapping postcolonial Central Europe: the book's structure 7

\section{PART I}

Whiteness: the never-ending story of epistemic injustice against Roma

1 Whiteness: a locus for doing race

Roma in Central Europe: obsession with whiteness 15

Critical whiteness: options for justice 16

Whiteness in Europe: the over-determination of racism 18

Central European resistance to critical whiteness: between overt reactionism and implicit eliminativism 19

Conclusion 21

2 Obscure racism: from national indifference to whitening Roma

National indifference in Central Europe: obscuring race and class 25

Fixing Jewish identity: in the footsteps of whiteness 27

Normalizing Roma: whitening the past 30

Conclusion 33 
vi Contents

3 The post-socialist shift in pathologizing: from disabled Roma to disabled socialism

Pathologizing vs. normalizing: the two extremes of "whitening" Roma 36

Victimizing Roma: a (post-)socialist pathway of objectification 38

Historicizing as a possible response to pathologizing: toward epistemic justice 40

Conclusion 41

4 The limits and options of historical narratives concerning

Roma in Central Europe

The normalizing and pathologizing of Roma as traditional narratives 44

Exemplary narratives in historicizing Roma: ruptures vs. continuities 45

Critical narratives of Central European history: losing Roma in transition 46

Quasi-genetic narratives of Roma: missing historical evidence 49

Conclusion 51

\section{PART II}

The (in)educability of Roma: Central Europe between overt and enlightened racism

5 The inception of whiteness: the Grellmannian intersections of European Roma

The Grellmannian dichotomies: introducing colonial discourse to the "Gypsy issue" 57

Non-human "Gypsies” vs. human Europeans: struggling for progress 60

Eternal children vs. masterful adults: unapproachable assimilation 62

The bestiality of "Gypsy" women vs. the whiteness of European men: toward the radical divergence of racial difference 63

Conclusion 65

6 Global racial order comes to Central Europe: the puzzle of "White Gypsies" at the dawn of the twentieth century

Racial intermixture in the Western world: the inception of racial intersectionality 69 
Postcolonial Europe in the focus of outsiders and insiders: deepening (non)whiteness 74

The threat of racial mixing in Central Europe: belligerent outsiders 75

Other Europeans? The view of benevolent outsiders 79

The response of insiders: adapting whiteness 82

Roma in the focus of insiders and outsiders: signifying peripheral Europe 84

Conclusion 90

7 The institutionalization of a racialized approach to Roma in the 1920s-1940s: rooting the stigma of an insecure population

A racialized approach to Roma in police surveillance: between the challenges of a global security agenda and nation-building 99

The doctrinal racism of František Štampach and Robert Ritter: the resonance of political will and personal choice 105

Schooling the (in)educable? The intraracial hierarchy of "Gypsy primitives" in action 112

Desirable "Gypsies" vs. unwanted others: an effective false antinomy in racializing Roma 117

Conclusion 121

8 In (re)search of inclusion: Roma under the pressure of de-historicizing between the 1950s and 1990s

Introduction 127

Post-Porajmos racism: whitening memories to exclude Roma 128

Roma in the global agenda of population studies: insecure populations vs. human progress 138

The "Gypsy issue" in the international agenda of human adaptability: the crystallization of the racist community 139

Implications for segregative practices: the outputs of the IBP in Czechoslovak policies concerning Roma 145

De-historicizing Roma in Czech socialist fiction: visualizing whiteness 147

Conclusion 155

Conclusion: epistemic justice for Central European Roma: toward the unlimited negation of whiteness 


\section{Figures}

6.1 White "Gypsy" children in Prekmurje 70

6.2 "Black Gypsies" and their physical degradation 88

7.1 The mixed "Gypsy" family: racial signifiers remain predominant among children

7.2 The comparison of Europeans and "Gypsies" 110

7.3 The phases of assimilation of European "Gypsies" 119

8.1 White supremacy in Můj pritel Fabian (My Friend the Gipsy, 1953)

8.2 White supremacy in Můj prítel Fabian (My Friend the Gipsy, 1953)

8.3 "Backwardness" of Roma in Mưj pritel Fabian (My Friend the Gipsy, 1953)

8.4 Pavel Křiž as Miroslav Dudek in Kdo se boji utíká (Who Is Afraid, Flees, 1986)

8.5 Pavel Křiž as Miroslav Dudek is playing Bach to Romani children in Kdo se bojí utiká (Who Is Afraid, Flees, 1986)

8.6 Romani children are dancing to their teacher's instruction in Kdo se bojí utíká (Who Is Afraid, Flees, 1986)

8.7 "White love" in the background of a "Gypsy" wedding in Kdo se bojí utíká (Who Is Afraid, Flees, 1986) 


\section{Acknowledgments}

We would like to thank our colleagues who have read the manuscript, in part or in whole, and who have made useful suggestions: Elena Maruschiakova, Veselin Popov, Karl Kaser and Christopher Donahue. We would like to single out the following for special thanks: Christian Promitzer for his concrete help with the general conception of Part II and Will Gay for sharing his research experience, decisive for completing the last chapter.

For providing access to primary sources, we would like to express our appreciation to all the archives in which the materials were collected. Our special thanks go to Petra Golja and her colleagues (Archive of the Group of Anthropology, Department of Biology, Biotechnical Faculty, University of Ljubljana, Slovenia); Jaroslava Fikejzová (The National Film Archive Library in Prague); Milena Běličová (Archive of the National Museum, Prague); and Dušan Slačka (Museum of Romani Culture, Brno). The authors would like to acknowledge the assistance of Mikhail Tsyganov in conducting archival studies in Prague and Ljubljana. We would like to express our appreciation to Kseniya Brailovskaya and Konstantin Gerbeev for conducting library research undeniably important for completing the text.

The staff of IQ Roma Service, Brno, deserves many thanks for all its help in making it possible to discuss the preliminary outputs of the survey with Roma. Victoria Shmidt would like to thank all students at the Faculty of Education, Masaryk University, Brno, who participated in the course "Education for Roma: Surveillance vs. Empowerment" between 2017 and 2019, and who have contributed to writing this book as friendly future readers.

The research for this text was sponsored by the Grant Agency of the Czech Republic, as part of the project "Child Welfare Discourses and Practices in the Czech Lands: The Segregation of Roma and Disabled Children during the Nineteenth and Twentieth Centuries" (15-10625S), and "Die Rassenkunde: Unentdeckte Macht des Aufbaus der Nationen" [Race Science: The Undiscovered Power of Building the Nation] by the FWF Austrian Science Fund (2674-G28). This research was also financially supported by the Grant Agency of Masaryk University, through the student research project "Migration and Contemporary Societies: Cultural Sociological Perspectives," project number MUNI/A/1157/2019. 


\section{Abbreviations}

\section{Archives}

Archiv Akademie Vèd České republiky Archive of the Academy of Sciences (AAV) Archive of the Group of Anthropology Department of Biology, Biotechnical Faculty, University of Ljubljana, Slovenia (AGA)

Archiv Karlovy univerzity Archive of Charles University (AUK)

Archiv Muzea romské kultury Archive of Museum of Romani Culture (MRK) Archiv Národniho Musea, Praha Archives of the National Museum, Prague (ANM) Archiv Univerzity Komenského Archive of Comenius University (UK(A)) Archiv Ústavu antropologie Přrirodovédecké fakulty Masarykovy University Archive of the Institute of Anthropology, Faculty of Natural Sciences, Masaryk University (AUA)

Národni filmový archiv, Praha National Film Archive, Prague (NFA)

Státni oblastní archiv v Třeboni State Regional Archives in Třeboň (SOA in Třeboň) Štátny archiv v Košiciach State Archives in Kosice (SaK) 


\section{Introduction}

\section{A longue durée of segregation against Roma: inside of whiteness}

In 1783, Heinrich Grellmann brought forward an analogy between "Gypsies" and African American slaves in order to stress the power of Europeans to civilize those considered non-white: "It may be hoped, that while we are endeavouring to ameliorate the condition of our African brethren, the civilisation of the Gipseys, who form so large a portion of humanity, will not be overlooked."1

In 1897, Leopold Glück offered linguistic and anthropological grounds for differentiating the "Gypsy" populations of Bosnia and Herzegovina, whose language evidenced their common Indian origin, but whose historical traces varied and led to two different "Black" and "White" profiles:

While the first remain half-nomadic and continue travelling during the warmer time, the latest are sedentarized. The Black Gypsies practice their religion, their women walk undressed, and they speak their own language. The White, sedentarized, Gypsies have rejected their religion, dress their women and adapt the rules of the regions where they settle. ${ }^{2}$

In 1943, Eva Justin opened her dissertation aimed at providing a solid argument against the previous politics of assimilation, and in the theoretical grounds for forced sterilization of Roma, she compared them to "white trash," one of the target groups for the U.S. eugenic agenda: "The whole society does not want to continue more than one-hundred years of dangerous state policy, and we all claim right now: 'No Gypsy trash!' [Nicht-Zigeuner-Gesindel]."3

In 1960, Eva Bačiková, an expert for the Ministry of Education and Culture in Czechoslovakia, directly criticized the previous trend to equate African Americans with Roma, typical of the socialist public discourse:

Led by positive intents to demonstrate that Gypsy children are successful too, able to achieve something too, our teachers present their Gypsy students as trained animals in the circus and sometimes they piggyback on the Gypsy topic. "Look, what our Gypsy children could do!" - our teachers say. At school, they are taught to sing their Gypsy songs as if they are a compliant choir of black slaves. Also, Gypsy children know neither Czech and Slovak folk music nor the pioneer songs. ${ }^{4}$ 


\section{Introduction}

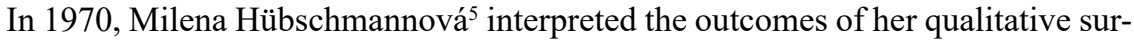
vey among non-Roma respondents by comparing their approaches towards the "Gypsy issue" with the practices of segregation against indigenous populations and African Americans:

The Gypsy issue has a world analogy. Its general character stems from the compatibility of the status of the minority group with the dominant society. History persuades us that the approaches which the dominant society applies to solving the issue of minorities in different places of the Earth are compatible. ${ }^{6}$

Her own approach to reject the labeling of Roma as asocial criminals also stemmed from the compatibility between Roma and savages, namely, the description of the Gabon tribe by Schweitzer:

In his book, On the edge of the primeval forest, Albert Schweitzer shares a very interesting example, namely, that the Gabon tribal people do not accept theft by those who do not belong to their tribe as an immoral act. The action, which is defined by "whites" as "lifting" is as natural for the Gabon as taking the fruits of Nature. I suppose that the same approach to evaluating theft was relevant for those Roma sentenced to the most extreme isolation. ${ }^{7}$

In 1976, the Czech educator Josef Štěpán, who was responsible for retraining socialist teachers in schools for Romani children, stressed the potential of comparing Roma and savages: "It would be interesting to think about the analogy between the ethnic group of Gypsies and the ethnic groups [tribes living on the island of Celebes, now known as Sulawesi], living at a low level of social development." 8

In 1993, the Hungarian psychologist Tamás Bereczkei applied the controversial approach by Philippe Rushton to exploring the reproductive strategies of Hungarian Roma. Rushton had ascribed to African Americans the predominance of an r-strategy of selection more compatible with animals than with white individuals, to whom Rushton prescribed a K-strategy. ${ }^{9}$ Later, this approach was reproduced by Serbian and Czech scholars. ${ }^{10}$

In 2004, Bob Hepple proclaimed a "second wind" for the U.S. Supreme Court's decision in the Brown v. Board of Education case, which had overturned the segregation of African Americans, applying the terms of the case to strategic litigation for the rights of Roma in Europe because "the 'rights of man' or 'civil rights' are a common inheritance of humanity." "1

The analogies between Romani and non-white populations - mainly African Americans and the indigenous groups of America and Australia - has a long historical tradition in shaping arguments in favor of either segregation or integration. Further, looking upon Roma as a non-white "race" established one of the core channels for translating whiteness to Europe. However, discussing the issues concerning Roma in Central Europe in terms of critical whiteness remains 
fragmented, or even more, an unwelcome theoretical pathway because of the multiple in-betweenness of Central European identity, as Ondřej Slačálek explained in his imaginary dialogue with Gayatri Chakravorty Spivak:

Dear Gayatri Chakravorty Spivak, you asked whether we were also postcolonial. It seems that you were looking to the post-communist countries for partners in experience, dialogue and solidarity. We are very sorry, but you will not find what you were looking for in Central Europe. Your question may cast light on some features of the post-socialist experience, but when we pose it rigorously we find barriers to the transfer of concepts at the analytical level, and in terms of the development of solidarity, on the level of political action. The basic barrier is that the fundamental anxiety of Central European countries is fear of being expelled from the West and put on to the same level as the colonised countries. ${ }^{12}$

Building upon the ideas of Slavoj Žižek, we might say that in the background of this fear, it is possible to recognize the identification of Central Europe with the West and with whiteness, not "imaginary," but "symbolic" - autonomous from the prescriptions to be aligned with Europeanness through experiencing and negating European identities. ${ }^{13}$ While "imaginary identification" involves identifying "with the image of the other inasmuch as we are 'like him," "14 "symbolic identification" aims to emancipate from such desirable but adopted patterns, through experiencing the identification with the other "at a point at which he is inimitable." 15 A part of this process, the ambivalent attitudes toward each of its former masters, has led Central Europe to sublimate the past and practice "reverse racism" - against those seen as barbarian colonizers.

Being in line with Western (white) standards also includes the contemporary equation of progress with human rights, offering the option of labeling both the Nazi and the Soviet regimes as barbarian and anti-European, especially with regard to the politics concerning minorities. This double opposition, barbarian colonizers vs. "masters" who aimed to enlighten, and Central Europe vs. the colonies of the Western world, inclines scholars to measure the region's own history of segregation in contrast to the extreme transgressions of the Nazi regime and to avoid accepting historical responsibility for the politics concerning minorities, which are measured against the atrocities of the Nazis. Among other driving forces, avoiding the reflection of such historical continuities aggravates the overdetermination of racism in the various realms of life for those relegated to proving their whiteness - namely, Roma. ${ }^{16}$

Following Levine-Rasky, we could say that in response to the threat of its loss, the identity of postcolonial Central Europe continues to be reproduced through mass education, popular culture, urbanization and migration. ${ }^{17}$ In the case of Roma, the argument in favor of injustice and segregation in education continues to play an outstanding role due to a long-term focus on the limited educability of Roma. Over the eighteenth, nineteenth and twentieth centuries, ineducability operated as a key theorized argument in favor of the most extreme forms of 
segregation, including forced sterilization and even extermination. Along with legitimizing segregation, theorizing ineducability laid the groundwork for negating Romani capacity as subjects of knowledge, which hindered practicing their identity and quite literally prevented Roma in Central Europe from becoming who they are. ${ }^{18}$

Due to its sacralized role in emancipation from a colonial past, the whiteness of Central Europe seems to be not only invisible but untouchable with regard to overcoming epistemic injustice - fostering a long-term deficit of credibility to those outsider groups whose knowledge has no status ${ }^{19}$ and limiting or even blocking access to collective interpretative resources, which places Roma at an unfair disadvantage when it comes making sense of their social experience. ${ }^{20}$

\section{Critical whiteness as the only option for epistemic justice for Roma in Central Europe: methodological grounds}

Miranda Fricker views epistemic justice as a regulator of the production and consumption of knowledge. While testimonial justice nurtures an economy of credibility, hermeneutical justice allows access to collective hermeneutical resources. Introducing these two interrelated types of justice immediately leads Fricker to a particular way of historicizing injustice as the output of practicing identity power, directly dependent upon shared social-imaginative conceptions of social identities. ${ }^{21}$ As a socially situated capacity to control the actions of others, power produces the prejudices that represent a historical-constitutive form of "bad epistemic and moral luck" - for those who segregate as well as those who become the objects of applying such power. ${ }^{22}$ This core concept in Fricker's approach prescribes accepting historical responsibility rather than attributing blame:

There have always been prejudices . . . but the prejudices that may be in the air at any given time change with history. We need a conception of human beings as formed by the attitudes of their time yet capable too of taking a critical stance towards those attitudes. ${ }^{23}$

Historicizing epistemic injustice calls for recognizing the cultural-historical setting of prejudices as opposed to abstract transhistorical conceptualization. Contextualizing prejudices provides the grounds for a further step, namely, recognizing historically available and unavailable critical concepts in order "to distinguish exceptional moral judgements from routine ones, producing injustice, and to explain how a piece of moral progress - the move away from a practice . . . is possible." ${ }^{24}$ Moreover, the task of differentiating routine and exceptional judgments faces a potential vacuum of hermeneutical resources for recognizing injustice: "[D]ifferent groups can be hermeneutically disadvantaged for all sorts of reasons, as the changing social world frequently generates new sorts of experience of which our understanding may dawn only gradually." 25 The inevitability of postponing hermeneutical justice provides the grounds for better understanding the power of prejudices which "can control our actions even despite our beliefs." 26 
In this way, epistemic justice revises one of the central issues of historicity, "the tension between stability or continuity on the one hand and change or development on the other," ${ }^{27}$ and one of the palpable risks of historical narration is sacrificed to "a paradox consisting of explicit skepticism of modernization and implicitly ascertained criticism of the past." 28 While historicizing should be led by the mission to overcome the extant routine of social interpretative habits that continue to serve injustice, the genetic narrative of injustice maps the practices aimed at reestablishing justice through revising the impact of whiteness. Comparing Fricker's approach with two other ways of conceptualizing the role of knowledge in segregation - the violence of knowledge (Edward Said) and the collision of recognition vs. redistribution (Nancy Fraser, Jürgen Habermas and Axel Honneth) - points to the potential of epistemic justice for historicizing whiteness in Central Europe.

Originally, the violence of knowledge has concentrated on the postimperial realm of social knowledge. Jeffrey Guhin and Jonathan Wyrtzen ${ }^{29}$ explore different but overlapping forms of the violence of knowledge: the violence of essentialization, epistemic violence and the violence of apprehension. The violence of essentialization decontextualizes local and personal experience, opposing it to global notions mostly drawn from the Western "cultural archive." Stressing the contrast between the right progressive values and local approaches claimed to be "dangerous" due to their "backwardness," epistemic violence relegates the knowledge of locals to the margins of the Western academy, destroying and preventing its production. The adherents of Said tend to indict the violence produced even by knowledge that is not essentialist in its origin, but from particular contexts, arguing that such violence of knowledge reinforces segregation. For instance, "knowledge about local culture, society, or religion often not totally inaccurate . . was then used to produce markers of native identity, the purpose of which was to reinforce a hierarchy between European colonizer and native colonized." ${ }^{30}$ Labeling this type of violence as the violence of apprehension, Guhin and Wyrtzen focus on those who abuse their power by using such static categories of native identity. Relevant examples can be found in the practice of the removal of children from indigenous populations because of the ostensive inability of their parents to ensure a proper education - according to the opinion of child protection services. ${ }^{31}$

While this matrix is fruitful for mapping epistemic injustice, its focus on the opposition between postimperial and local knowledge represents the inevitable risk of transforming any knowledge into a tool of epistemic injustice: " [I]f culture can stand up against the State and not only add to its power, then there is some possibility for more or less accurate knowledge that does not immediately contribute to the three violences we describe." ${ }^{32}$ Prescribing this pathway toward social knowledge not only misses the task of recognizing hermeneutical resources suitable for restoring epistemic justice but also ignores the specifics of the violence of knowledge produced in postcolonial Central Europe, where theories affiliated with the Western academy remain seemingly untouchable for critical revision. Indeed, attachment theory or racial assimilationism, elaborated by the scholars of Central Europe, are still seen in opposition to the pressure of Soviet dogmatic pseudoscience. The deconstruction of these theoretical arguments requires not 


\section{Introduction}

only applying the violence of knowledge matrix but also recognizing the historical wrongs of these theories concerning minorities - in terms of whiteness - and accepting responsibility for their reproduction.

The limits of the violence of knowledge concept reverberate with an important dilemma: the consistent negation of injustice vs. the risk of producing trivial knowledge that embeds the case of Central Europe in a range of contexts limited by understanding biopolitics as "a specific modern form of exercising power." 33 The recently disseminated trend to recognize in the knowledge produced by anthropologists or eugenicists in Central Europe an instrument of biopolitics "calls into question the topology of the political." 34 For instance, the shift from an organicist concept of biopolitics as the intention of the state to be aligned with biological laws to racist biopolitics aimed at designating an "authoritarian, hierarchically structured, and racially homogeneous community of people's body" 35 has varied from country to country due to different political backgrounds, including the vicissitudes of the colonial experience and the scenarios of deliberation.

The collision of redistribution vs. recognition emphasizes another dilemma in historicizing epistemic injustice as the grounds for restoring justice: the inevitable asymmetry between the intention to be a virtuous hearer (and to stop producing testimonial injustice) and the impossibility of avoiding the pressure of shared stereotypes. Opposing redistribution (social equality, access to social rights) to recognition (various practices of acceptance and tolerance) is often seen through the lens of the complex relationship between justice and democracy. ${ }^{36}$

A very early approach developed during the "golden age" of the welfare state sets forth the role of social rights in promoting democratic rights, but changes in the global labor market and migration have transformed the role of citizenship and brought into focus the role of democratic rights for promoting social rights. Also, this approach faces the issue of recognition - accepting Otherness even within limited access to social rights. Honneth and Fraser offer two ways to cope with this dilemma. While Honneth emphasizes the role of social rights for ensuring recognition, in the late 1990s Fraser had stressed the prerequisite of recognition for practicing democratic rights but also opposed them to social rights. ${ }^{37}$ In this dichotomy, she mentions post-socialism in particular as a primary factor in reproducing the dilemma of recognition vs. redistribution. ${ }^{38}$ Later, Fraser reinforces the role of the political in exploring possible ways toward justice. In an interview given to George Yancy in 2015, ${ }^{39}$ Fraser reconstructs this argumentation by introducing another dichotomy, expropriation vs. exploitation, which differentiates "laborers" and "slaves." She easily transforms the question asked by Yancy ("In what specific ways must capitalism, because it is always already linked to racism, be restructured?") into "Is it possible to abolish racial oppression without abolishing capitalism?" answering in terms of ideological affiliations:

Contra traditional understandings of socialism, an exclusive focus on exploitation cannot emancipate working people of any color; it is necessary also to target expropriation. ... By the same token, contra liberal and "progressive" anti-racists, an exclusive focus on discrimination, ideology and law, is not 
the royal road to overcoming racial oppression. . . . Both projects require a deeper radicalism - one aimed at structural transformation of the overall social matrix, at overcoming both of capitalism's exes [expropriation and exploitation] by abolishing the system that generates their symbiosis. ${ }^{40}$

The theoretical dualism between structure and culture has led Fraser's critics to rearrange the relations between economic and interpersonal drivers of injustice to emphasize the multilevel contradictions palpable at the micro-institutional and local levels, in contrast to the macro-structural approach offered by Fraser. According to Judith Butler, the polarization of economic and cultural justice as analytically distinct does not reflect the complex political realities and intersections of justice claims. ${ }^{41}$ Indeed, what are the prerequisites for being able to practice recognition? How can we ensure the production of the knowledge indispensable to practicing recognition? These questions mark the main critical point in the debates between Fraser and her critics, regarding what the "proper" historically situated knowledge of modern society is, and who produces this knowledge. The recent attempts to apply Fraser's matrix to the issue of Roma inevitably emphasize neoliberal politics as a main factor in reproducing structural violence against Roma $^{42}$ and neglect the task of specifying the historical continuity between (1) the longterm history of applying analogies with non-white people to Roma and (2) contemporary moral campaigns against Roma stemming from the migrant "crisis."

Fricker, who consistently interlinks epistemic injustice with other types of injustice, introduces a solid argument in favor of reflecting the various factors leading to recognition as a part of practicing epistemic justice. The core driving force of epistemic injustice - identity power - "typically operates in conjunction with other forms of social power. Consider a social order in which a rigid class system imposes an asymmetrical code of practical and discursive conduct on members of different classes. ${ }^{\not 33}$ While epistemic injustice reestablishes the relationship among social settings, the position of a single hearer or producer of knowledge directly depends on social status: "[H]ermeneutical marginalization entails marginalization of a socioeconomic sort, since it entails non-participation in professions that make for significant hermeneutical participation (journalism, politics, law, and so on). ${ }^{{ }^{\prime 44}}$ Applying this approach to Central Europe allows us to revise simplistic views of the socialist period as a period of economic equality and to deepen our understanding of particular forms of structural injustice established and fixed during that period. In this turn, the impact of historical continuities on reproducing injustice calls for recognizing the driving forces behind structural violence - with a focus on whiteness as an agent and a structure of nation-building in Central Europe.

\section{Remapping postcolonial Central Europe: the book's structure}

As long as whiteness operates as an invisible but influential framework for injustice, including unequal access to producing and disseminating knowledge concerning segregation against minorities, historicizing Roma in Central Europe calls 


\section{Introduction}

for redefining the formation of postcolonial Central Europe as orchestrated by the desire to obtain whiteness. This book aims to solve two interrelated tasks: (1) to deconstruct the contemporary obstacles to accepting the legacy of whiteness in the history of Roma in Central Europe and (2) to retell the history of Roma as a genetic narrative of whiteness in the region. The book consists of two parts. Part I aims to fix the entire apparatus of collective social meaning effectively geared toward keeping the obscured experience of whiteness out of sight. ${ }^{45}$ Part II explores the ineducability of Roma as a structuration of whiteness, a product of practices racializing Roma and one of the core arguments made by those who produced whiteness - scholars and public experts.

The first part of the book, "Whiteness: the never-ending story of epistemic injustice," redefines whiteness as a key source of the ongoing reproduction of epistemic injustice against Roma in Central Europe, even amid attempts to restore access for Roma to provide testimonies and produce collective hermeneutical resources concerning their experience. It is thematized according to three main post-socialist pathways in historicizing injustice against Roma that moderate the exchange of testimonies: (1) pathologizing the past of Roma; (2) normalizing (whitening) Roma by embedding their history in transnational and transhistorical concepts such as human rights; and (3) remarginalizing collective and individual memories of Roma concerning the daily practices of survival as the core for understanding the historical continuities in injustice and the attempts to overcome them. ${ }^{46}$

We focus on the outward and inward commensurability of each of the pathways with injustice in terms of whiteness and options for achieving justice. While these pathways have moved beyond the frontiers of academia and started to influence public discourses concerning Roma, including massive visualization efforts in films, exhibitions, museum expositions and memorials, we examine them as either providing or blocking the options for restoring epistemic trustworthiness to Roma, ensuring two distinct components - competence and sincerity - as well as the frameworks for emancipating scholars from the pressure of whiteness.

Part II, "The (in)educability of Roma: Central Europe between overt and enlightened racism," historicizes the idea of the (in)educability of Roma in line with its dual role in producing whiteness. Recognizing justice as a process aimed at radically negating injustice, rather than a maximally abstracted rational idealization of human beings, calls for a clear criterion of historically significant events that initiate or constitute ruptures, mutations or, more generally, transformations in social forms of injustice. ${ }^{47}$ By exploring different approaches to theorizing the (in)educability of Roma and their historical interrelation, we revise the racialization of Roma as a process of "layering" (the partial renegotiation of some elements while leaving previously established elements in place) and "conversion" (using existing practices and discourses in the service of new goals) ${ }^{48}$ of the theorized arguments and the practices that led to multilevel segregation of Roma as non-white, including the negation of their capacities as the subjects of knowledge about themselves and their past. 
The main sources for this analysis include academic journals, as well as materials housed in the State Archives in Košice, Slovakia (SaK); the Archive of the Group of Anthropology, Department of Biology, Biotechnical Faculty, University of Ljubljana, Slovenia; the Třebon̆ Regional Archives, Czech Republic; the Archive of the Museum of Romani Culture, Brno, Czech Republic; the Archive of the Institute of Anthropology, Masaryk University, Brno, Czech Republic; the Archive of the National Museum in Prague; and the Archive of the Academy of Sciences of the Czech Republic in Prague.

The retrospective analysis in the four chapters comprising Part II collocates chronological and thematic approaches to historical narration that represent four interrelated time-space realms that have infiltrated education with whiteness: (1) one of the earliest attempts to establish the politics of enforced assimilation of Roma during Maria Theresa's reforms, reflected in an essay by Heinrich Moritz Gottlieb Grellmann (1756-1804); (2) the application of recapitulation theory to defining the status of postcolonial Central Europe in the global racial order and using the argument regarding the presence of "White Gypsies" either in favor of or against defining Central Europe among whites; (3) the interrogation of two main approaches for institutionalizing a racialized approach to Roma between the 1920s and 1940s and constructing Roma as an ineducable ethnic group at high risk for social security: either mixing with "lower" racial groups or, conversely, the lack of biological drift; and (4) the growing meta-racism during the postwar period, explored through deconstructing the politics aimed at ensuring inclusion of Roma and revising the crystallization of the international community of racially minded experts.

Cynthia Levine-Rasky stresses the importance of understanding how the meaning of whiteness has been constructed in the social imagination in particular times and places. While "philosophical, theological, and scientific thought converged to produce a comprehensive rationale for the distinction between whiteness and all deviations from this ideal," 49 our historical responsibility cries out for comprehensive deconstruction of this pathway.

\section{Notes}

1 In 1807, Grellmann's thesis was translated into English and published in London. Stylistically, and in terms of content, this English translation fully reproduced the original German version of Grellmann's text. We used this translation - without changing the orthography and syntaxes. Heinrich Moritz Gottlieb Grellmann (1807) Dissertation on the Gipseys: Representing Their Manner of Life, Occupations and Trades, Marriages and Education, Sickness, Death and Burials, Religion, Sciences, Art, London, William Ballintine, p. 99.

2 Leopold Glück (1897) Zur physischen Anthropologie der Zigeuner in Bosnien und der Hergegovina: Die mohammedanischen Zigeuner [About the Physical Anthropology of Gypsies in Bosnia and Hercegovina: Muslim Gypsies], in Wissenschafliche Mitteilungen aus Bosnien und der Hercegovina [Scientific news from Bosnia and Hercegovina], Vol. 3, Wien, S. Gerold Sohn, pp. 403-433.

3 Eva Justin (1943) Lebensschicksale artfremd erzogener Zigeunerkinder und ihrer Nachkommen [The Destiny of Gypsy Children Brought Up Out of Families and 


\section{Introduction}

Observation Under Them], Doctoral Thesis, Friedrich Wilhelms Universität, Berlin, p. 32.

4 Jan Štrup and Eva Bacíková (eds.) (1960) Zkušenosti z práce mezi cikánským obyvatelstvem 1. sborniček [The Experience of Working among Gypsies: First Part], Praha, Osvětový ústav v Praze [The Institute of Enlightenment], p. 3.

5 Milena Hübschmanová (1970) Co je tzv. cikánská otázka? [What is the So-called Gypsy Problem?] Sociologický Časopis, 6, 2, pp. 105-120.

6 Ibid, p. 109.

7 Ibid, p. 113.

8 J. Štěpán (1976) K lateralitě mentální retardovaných žáků cikánského původu [About the Laterality of Mentally Retarded Students of Gypsy Origin], Otázky defektologie, 8, pp. 316-320, 317.

9 Tamás Bereczkei (1993) r-Selected Reproductive Strategies Among Hungarian Gypsies, Ethology and Sociobiology, 14, pp. 71-88.

10 Jelena Čvorović (2004) Sexual and Reproductive Strategies Among Serbian Gypsies, Population and Environment, 25, 3, pp. 217-242.

11 Bob Hepple (2006) The European Legacy of Brown v. Board of Education, University of Illinois Law Review, 4, 5, pp. 605-625, 609.

12 Ondřej Slačálek (2016) The Postcolonial Hypothesis: Notes on the Czech "Central European" Identity, Annual of Language \& Politics and Politics of Identity, 10, pp. $27-44,40$.

13 Slavoj Žižek (1989) The Sublime Object of Ideology, London and New York, Verso.

14 Ibid, p. 121.

15 Ibid.

16 Cynthia Levine-Rasky (2013) Whiteness Fractured, Surrey, Ashgate, p. 13.

17 Ibid, p. 18.

18 Miranda Fricker (2007) Epistemic Injustice: Power \& the Ethics of Knowing, Oxford, Oxford University Press.

19 Levine-Rasky, p. 11.

20 Fricker, p. 1.

21 Ibid, p. 4.

22 Ibid, p. 103.

23 Ibid, pp. 81-82.

24 Ibid, p. 107.

25 Ibid, p. 151.

26 Ibid, p. 15.

27 Stefan Benz (2017) Measurable Effects of Denominations on Narrative Patterns: The German Case of Diversity in Narrating Histories, Historical Social Research/Historische Sozialforschung, 42, 2, pp. 170-196, 171.

28 Ibid, pp. 179-180.

29 Jeffrey Guhin and Johnathan Wyrtzen (2013) The Violence of Knowledge: Edward Said, Sociology and Post-orientalist Reflexivity, in Julian Go (ed.) Political Power and Social Theory: Postcolonial Sociology, Bradford, Emerald Insight, pp. 231-262.

30 Ibid, p. 244.

31 Shannon O'Gorman (2013) Towards a Second-Order View of Child Protection Placement-Related Decision-Making, Child and Family Social Work, 18, pp. 403-416.

32 Guhin and Wyrtzen, pp. 257-258.

33 Thomas Lemke (2011) Biopolitics: An Advanced Introduction, New York, New York University Press, p. 9.

34 Ibid, p. 31.

35 Ibid, p. 11.

36 Katrin Toens (2007) The Dilemma of Regress: Social Justice and Democracy in Recent Critical Theory, European Journal of Political Theory, 6, pp. 160-179.

37 Ibid, p. 165. 
38 Nancy Fraser (1997) Justice Interruptus: Critical Reflections on the "Postsocialist" Condition, New York, Routledge.

39 Between November, 2014 and December, 2015, George Yancy interviewed 19 philosophers who specialize in various aspects of the topic of race for the New York Times philosophy column, "The Stone.” In 2017, a book featuring all the interviews (On Race: 34 Conversations in a Time of Crisis, Oxford, Oxford University Press) was published.

40 George Yancy (2017) On Race: 34 Conversations in a Time of Crisis, Oxford, Oxford University Press, p. 164.

41 Kevin Olson (ed.) (2008) Adding Insult to Injury: Nancy Fraser Debates Her Critics, New York, Verso.

42 Angéla Kóczé and Márton Rövid (2017) Roma and the Politics of Double Discourse in Contemporary Europe, Identities, 24, 6, pp. 684-700.

43 Fricker, p. 15.

44 Ibid, pp. 155-156, emphasis in original.

45 Ibid, p. 153.

46 Julia Sardelić (2018) In and Out from the European Margins: Reshuffling Mobilities and Legal Statuses of Romani Minorities between the Post-Yugoslav Space and the European Union, Social Identities, 24, 4, pp. 489-504, 492.

47 Roy Bhaskar (2008) Dialectic: The Pulse of Freedom, London, Routledge, p. 41.

48 Kathleen Thelen (2003) How Institutions Evolve: Insights from Comparative Historical Analysis, in James Machoney and Dietrich Rueschemeyer (eds.) Comparative Historical Analysis in the Social Sciences, New York, Cambridge University Press, pp. 208-240, 213, 225, 228.

49 Levine-Rasky, p. 157. 


\section{References}

1 The Czech abbreviation for the title of bachelors degree.

2 The Czech abbreviation for the title of masters degree.

3 Plamena Stoyanova (2017) Tsiganite $v$ godinite na sotsializma. Politikata na b'lgarskata d'rzhava k'm tsiganskogo malitsinstva (1944-1989) [The Gypsies During Socialism: State Policy Concerning the Gypsy Minority in Bulgaria (1944-1989)], Sofia, Paradigma.

4 Victoria Shmidt (2018) Public Health as an Agent of Internal Colonialism in Interwar Czechoslovakia: Shaping the Discourse About the Nation's Children, Patterns of Prejudice, 52, 4, pp. 355-387.

5 István Kemény (2004) History of Roma in Hungary, available online at https://kisebbsegkutato.tk.mta.hu/uploads/files/archive/310.pdf.

6 Bartulin, Nevenko (2014) The Racial Idea in the Independent State of Croatia: Origins and Theory, Leiden, Brill.

7 Elisabeth Young-Bruehl (1996) The Anatomy of Prejudices, Cambridge, MA, Harvard University Press, p. 364.

8 Miranda Fricker (2007) Epistemic Injustice: Power \& the Ethics of Knowing, Oxford, Oxford University Press, pp. 53-54.

9 Ibid.

10 Ibid, p. 98.

11 Susan Young and Joanna Zubrzycki (2011) Educating Australian Social Workers in the Post-Apology Era: The Potential Offered by a "Whiteness" Lens, Journal of Social Work, 11, 2, pp. 159-173.

12 Teresa J. Guess (2006) The Social Construction of Whiteness: Racism by Intent, Racism by Consequence, Critical Sociology, 32, 4, pp. 649-673.

13 Slavery studies comprises transhistorical and transnational dimensions by stressing the fact that slavery and race had become interchangeable by the end of the European Middle Ages; see Colin Palmer (1996) Rethinking American Slavery, in Alusine Jalloh and Stephen E. Maizlish (eds.) African Diaspora, College Station, Texas A\&M University Press, pp. 73-99, 75.

14 Peggy McIntosh (1989) White Privilege: Unpacking the Invisible Knapsack, available online at https://nationalseedproject.org/Key-SEED-Texts/white-privilege-unpackingthe-invisible-knapsack.

15 Cynthia Levine-Rasky (2002) Working through Whiteness: International Perspectives, Albany, State University of New York Press, p. 18.

16 Melissa Steyn and Daniel Conway (2010) Introduction: Intersecting Whiteness, Interdisciplinary Debates, Ethnicities, 10, 3, pp. 283-291.

17 Terrance MacMullan (2005) Beyond the Pale: A Pragmatist Approach to Whiteness Studies, Philosophy and Social Criticism, 31, 3, pp. 267-292.

18 W. E. Burghardt Du Bois (1898) The Study of the Negro Problems, The Annals of the American Academy of Political and Social Science, 11, January, pp. 1-23.

19 MacMullan, pp. 271, 273.

20 Lucius T. Outlaw (2014) If Not Race, Then What? Bio-Cultural Groups, Social Ontology, Political Philosophy, Graduate Faculty Philosophy Journal, available online at www. academia.edu/12405745/If_Not_Races_then_What_Toward_a_Revised_Understanding of_Bio-Social_Groupings.

21 MacMullan, p. 281.

22 Ibid, p. 273.

23 Ibid, p. 279.

24 Montag Warren (1997) The Universalization of Whiteness: Racism and Enlightenment, in Mike Hill (ed.) Whiteness: A Critical Reader, New York, New York University Press, pp. 281-293.

25 Fricker, p. 4. 
26 Being forcibly sterilized in 1990, Gorolová is one of the most visible Romani activists who struggles to achieve redress for Romani women who were sterilized.

27 Elena Gorolová - Show Jana Krause 1 May 2019, available online at www.youtube. com/watch? $=$ MhgKACEOx9E.

28 The current populist prime minister and one of the wealthiest business owners in the Czech Republic.

29 Homi K. Bhabha (1998) Anxiety in the Midst of Difference, Political and Legal Anthropology Review, 21, 1, pp. 123-137, 124.

30 Levine-Rasky, p. 18.

31 MacMullan, p. 278.

32 Hallvard Fossheim (2019) Past Responsibility: History and the Ethics of Research on Ethnic Groups, Studies in History and Philosophy of Biological and Biomedical Sciences, 73, pp. 35-43, 36.

33 Gabriele Griffin with Rosi Braidotti (2002) Whiteness and European Situatedness, in Gabriele Griffin and Rosi Braidotti (eds.) Thinking Differently: A Reader in European Women's Studies, London and New York, Zed Books, pp. 221-246, 225.

34 Alastair Bonnet (1998) How the British Working Class Became White: The Symbolic (Re)formation of Racialized Capitalism, Journal of Historical Sociology, 11, 3, pp. 316-340.

35 Everett Cherrington Hughes (1945), Dilemmas and Contradictions of Status, American Journal of Sociology, 50, 5, pp. 353-359, 357.

36 This pejorative concept was used by the Nazis for labeling the offspring of AfroGerman relations, who were subjected to a policy of enforced sterilization. During the occupation of the Rhineland by Entente, mainly French troops comprised of privates from the French colonies of Algeria and Morocco, were blamed for the massive rape of German women. National and international campaigns shaped the image of Africans as sexual predators and after the Nazi seizure of power, the echo of a moral panic was reflected in the decision to sterilize those labeled as the offspring of sexual violence. See Julia Roos (2009) Women's Rights, Nationalist Anxiety, and the "Moral" Agenda in the Early Weimar Republic: Revisiting the "Black Horror" Campaign against France's African Occupation Troops, Central European History, 42, September, pp. 473-508.

37 Leo Lucassen (1996) Zigeuner: Geschichte Eines politischen Ordnungsbegriffes in Deutschland 1700-1945 [Gypsies: The History of One Political Master Concept in Germany between 1700 and 1945], Köln, Weimar and Wien, Böhlau Verlag, pp. 202-203.

38 France Winddance Twine and Charles Gallagher (2008) The Future of Whiteness: The Map of the "Third" Wave, Ethnic and Racial Studies 31, 1, pp. 4-24, 5.

39 Ibid, p. 9.

40 Anikó Imre (2005) Whiteness in Post-Socialist Eastern Europe: The Time of the Gypsies, The End of the Race, in Alfred López (ed.) Postcolonial Whiteness: A Critical Reader on Race and Empire, Albany, NY, State University of New York Press, pp. 79-102, 84.

41 Philip Rushton (1988) Do r/K Reproductive Strategies Apply to Human Differences? Social Biology, 35, 3-4, pp. 337-340. r/K theory prescribes to each animal species one of two strategies of reproduction: either in a stable environment where less but better offspring are created or in an unstable one where more and worse offspring are born. Animals on the $r$-path survive on unexploited ecological niches. Animals on the $K$ - path are strong competitors for resources in crowded niches. Human beings were primarily seen by $\mathrm{r} / \mathrm{K}$ theory as belonging to the latter.

42 Petr Bakalář (2003) Tabu v sociálních vědách [Taboo in Social Science], Praha, Votobia, p. 22.

43 Ibid, p. 14. 
44 MacMullan, p. 270.

45 Along with this book, Bakalár published several articles concerning the limited ability of Roma to become civilized, including Petr Bakalar (2004) The IQ of Gypsies in Central Europe, Mankind Quarterly, 44, 3 \& 4, pp. 291-300, 292.

46 Petr Bakalár (2004) Psychologie Romů [The Psychology of the Roma], Praha, Votobia, p. 21.

47 Victoria Shmidt (2019) The Politics of Disability in Interwar and Socialist Czechoslovakia: Segregating in the Name of the Nation, Amsterdam, Amsterdam University Press.

48 Genetic drift can cause major losses in genetic variation for small populations.

49 Bakaláŕ (2004), p. 20.

50 David Halatka (2004) Nová rasistická kniha: Psychologie Romů? [New Racist Book: Psychology of the Roma?], available online at www.blisty.cz/2004/6/16/art18538. html.

51 Petr Třešňák (2004) S Bakalářem se nemluvi [With Bakalář, There Is No Discussion], available online at www.respekt.cz/tydenik/2004/23/s-bakalarem-se-nemluvi.

52 George Lipsitz (2006) The Possessive Investment in Whiteness: How White People Profit from Identity Politics, Philadelphia, PA, Temple University Press, p. 130. The metaphor of the iceberg was proposed by Gilbert Gee and Chandra Ford as a way of understanding structural racism, which they define as the interaction of the larger systems, forces, ideologies, institutions and processes that generate and reinforce unequal conditions among different racial groups.

53 According to constructivists, whiteness operates primarily as a routine order for moral and practical reasoning, perpetuating unnoticed habits in unjust situations; more in MacMullan, p. 284.

54 MacMullan, p. 283.

55 EDUin (2017) Denik Referendum: 10 let po rozsudku D. H. - Předsudky pedagogù a 83 segregovaných škol [Deník Referendum: 10 Years after the Judgment of DHPrejudices of Educators and 83 Segregated Schools], available online at www.eduin. cz/clanky/denik-referendum-10-let-po-rozsudku-d-h-predsudky-pedagogu-a-83segregovanych-skol/.

56 EDUin (2013) Podivejte se: Na kulatém stole se většina debatujicích vyslovila pro inkluzi [See For Yourself: At the Roundtable, Most of the Debates Were in Favor of Inclusion], available online www.eduin.cz/audio-a-video-archiv/podivejte-se-na-kulatemstole-se-vetsina-debatujicich-vyslovila-pro-inkluzi/.

57 Fossheim, p. 35.

1 Kateřina Capková (2012) Czechs, Germans, Jews: National Identity and the Jews of Bohemia, New York and Oxford, Berghahn Books, p. 118.

2 Will Guy (2019) Book Review of: Celia Donert (2017) The Rights of the Roma: The Struggle for Citizenship in Postwar Czechoslovakia, Cambridge, UK, Cambridge University Press, Intersections: East European Journal of Society and Politics, 4, 3, pp. 195-198.

3 Capková (2012), p. 4.

4 Tara Zahra (2010) Imagined Noncommunities: National Indifference as a Category of Analysis, Slavic Review, 9, 1, pp. 94-119, 116.

5 Alex Toshkov (2010) The Phantom Subject of "National Indifference": A Response to Tara Zahra, Imagined Noncommunities: National Indifference as a Category of Analysis, Slavic Review, 69, 1, p. 94, available online at www.slavicreview.illinois. edu/discussion/Toshkovessay-onZahra-final.htm\#_ftnref5.

6 Zahra, p. 119.

7 Michal Kopeček (2019) Czechoslovak Interwar Democracy and its Critical Introspections, Journal of Modern European History, 17, 1, pp. 7-15. 
8 Rebekah Klein-Pejšová (2015) Mapping Jewish Loyalties in Interwar Slovakia, Bloomington, Indiana University Press, pp. 48-49.

9 Ibid, p. 47.

10 Emanuel Rádl (1929) Národnost jako vědecký problém [Nationality as a Scientific Issue], Praha, O. Girgal, p. 83.

11 Ibid, pp. 71-72.

12 Ibid, p. 60.

13 Toshkov.

14 Eric L. Goldstein (2006) The Price of Whiteness: Jews, Race, and American Identity, Princeton, NJ, Princeton University Press, p. 42.

15 One of the recent trends is to use the strategies that proved their efficiency in legitimizing Jews as the victims of genocide to the case of Central European Roma: "There is a big difference in the outputs of the efforts make Holocaust visible for the public; for instance, survivors are invited to schools. It is still missing concerning the Roma community" (Upírané dějiny Romů. Rozhovor s Kateřinou Čapkovou, Helenou Sadílkovou a Pavlem Balounem [Blocking the History of the Roma: A Talk with Kateřina Čapková, Helena Sadílkova and Pavel Baloun], available online: www.novinky.cz/ kultura/salon/468655-upirane-dejiny-romu-rozhovor-s-katerinou-capkovou-helenousadilkovou-a-pavlem-balounem.html). While the reflection of the price of whiteness paid by Jews remains underrated, such analogies aggravate the hidden agenda of whiteness concerning Roma.

16 Tomás R. Jiménez (2010) Affiliative Ethnic Identities: A More Elastic Link between Ethnic Ancestry and Culture, Ethnic and Racial Studies, 33, 10, pp. 1756-1775.

17 Marie L. Miville and Angela D. Ferguson (2014) Handbook of Race-Ethnicity and Gender in Psychology, New York, Springer, p. 51.

18 Ann Morning (2018) Kaleidoscope: Contested Identities and New Forms of Race Membership, Ethnic and Racial Studies, 41, 6, pp. 1055-1073.

19 Wendy Brown (2005) Political Idealization and Its Discontents, in Wendy Brown (ed.) Edgework: Critical Essays on Knowledge and Politics, Princeton, Princeton University Press, pp. 17-36.

20 Wendy Brown (1993) Wounded Attachments, Political Theory, 21, 3, pp. 390-410, 391.

21 Čapková (2012), p. 245.

22 Kateřina Čapková (2016) Beyond the Assimilationist Narrative: Historiography on the Jews of the Bohemian Lands and Poland after the Second World War, Studia Judaica, 19, 1, 37, pp. 129-155.

23 Čapková (2012), p. 191.

24 Steve Garner (2007) Whiteness: An Introduction, London, Routledge.

25 Čapková (2012), p. 253.

26 Frederik Barth (ed.) (1969) Ethnic Groups and Boundaries: The Social Organization of Cultural Difference, Boston, Little, Brown and Company, p. 10.

27 Brown, p. 395.

28 Ibid, p. 403.

29 Čapková (2016), p. 140.

30 Goldstein, p. 42.

31 Ibid, p. 49.

32 Ibid, p. 86.

33 Amos Morris-Reich (2006) Project, Method, and the Racial Characteristics of Jews: A Comparison of Franz Boas and Hans F. K. Günther, Jewish Social Studies: History, Culture, Society, 13, 1, pp. 136-169.

34 Christopher M. Hutton (2005) Race and the Third Reich: Linguistics, Racial Anthropology and Genetics in the Dialectic of Volk, Cambridge, UK, Polity, p. 16.

35 Amos Morris Reich (2010) Circumventions and Confrontations: Georg Simmel, Franz Boas and Arthur Ruppin and Their Responses to Antisemitism, Patterns of Prejudice, 
44, 2, pp. 195-216, 209; Doron Avraham (2013) The "Racialization" of Jewish SelfIdentity: The Response to Exclusion in Nazi Germany, 1933-1938, Nationalism and Ethnic Politics, 19, 3, pp. 354-374.

36 Veronika Lipphardt (2008) Biologie der Juden: jüdische Wissenschaftler über "Rasse" und Vererbung 1900-1935 [The Biology of Jews: Jewish Scholars about "Race" and Inheritance 1900-1935], Göttingen, Vandenhoeck \& Ruprecht.

37 Ibid.

38 Klein-Pejšová, p. 144.

39 Roger I. Simon (2013) The Public Rendition of Images Médusées: Exhibiting Souvenir Photographs Taken at Lynchings, in Ranjan Ghosh and Ethan Kleinberg (eds.) America in Presence: Philosophy, History, and Cultural Theory for the Twenty-First Century, Ithaca, NY, Cornell University Press, pp. 79-102, 83.

40 Celia Donert (2017) The Rights of the Roma: The Struggle for Citizenship in Postwar Czechoslovakia, Cambridge, UK, Cambridge University Press, p. 5.

41 Ibid, p. 4, emphasis ours.

42 For instance, the attempts by some sedentarized Roma, targeted for assimilation, to be released from obligatory monitoring, or the numerous legal cases of Slovak Roma who wished to return to Slovakia after spending several months in Bohemian dispersion programs, do not figure as examples of fighting for rights.

43 Donert, p. 216.

44 Victoria Shmidt (2019) The Politics of Disability in Interwar and Socialist Czechoslovakia: Segregating in the Name of the Nation, Amsterdam, Amsterdam University Press.

45 Donert, p. 29.

46 The historical inaccuracy of Donert in prescribing to Malá a central role in launching anthropological research on Roma in the early 1960s, who was too young (26 years old) for such a position, and instead mentioning the leader, Jaroslav Suchý, a former doctoral student of Malý and supervisor of Malá, reflects the lack of systematic attention to the role of race science in legitimizing the segregation of Roma in postwar Czechoslovakia.

47 Donert, pp. 169-170.

48 Both Schultz and Malý elaborated the issue of Roma, with the first articles by Malý about the "Gypsy issue" appearing during the Protectorate period.

49 Donert, p. 229.

50 Targeted at recognizing how the necessity to meet science in their argument against scientific racism limited anti-racist African American scholars, Stepan and Gilman elaborate three pathways for internalizing dominant, racial, discourse: cannibalization, disarticulation and reassemblage. See Nancy Leys Stepan and Sander L. Gilman (1993) Appropriating the Idioms of Science: The Rejection of Scientific Racism, in Sarah Harding (ed.) The "Racial" Economy of Science toward a Democratic Future, Bloomington, Indiana University Press, pp. 170-193, 179.

51 Ibid.

52 Ibid.

53 Hallvard Fossheim (2019) Past Responsibility: History and the Ethics of Research on Ethnic Groups, Studies in History and Philosophy of Biological and Biomedical Sciences, pp. 73, 38.

54 Ibid.

55 Miranda Fricker (2007) Epistemic Injustice: Power \& the Ethics of Knowing, Oxford, Oxford University Press, p. 1.

56 bell hooks (1989) Talking Back: Thinking Feminist, Thinking Black, Boston, South End Press, p. 113. 
1 Jan Foll (1995) Dotočí Petr Václav svůj celovečerní debut Marian? Outsideři na vedlejších kolejích [Will Petr Václav Make His Feature Debut Marian? Outsiders on the Sidelines], Lidové noviny, 11.10.1995, s. VIII, č. 238.

2 Filmová a televizní fakulta Akademie múzických umění v Praze (Film and TV School of the Academy of Performing Arts in Prague).

3 Jan Šikl and Petr Václav (1993) Marian Námět, synopse, literární scénář [Marian: Theme, Synopsis, Literary Script], Národní Filmový Archiv, Knihovna.

4 Requiem pro panenku [Requiem for a Maiden] by Filip Renč (1991) and Kolja by Jan Sverrak (1996) are the clearest examples of this trend in early post-socialist Czech film.

5 Correctional institutions.

6 Diagnostický ústav, or in the Czech slang definition, past'ák, refers to residential care institutions aimed at providing the most appropriate placement for children in conflict with the law. The word pasták originates from the Czech past, meaning trap but also pastýr, meaning shepherd or pastor.

7 Šikl and Václav 1993.

85 otázek pro Jana Šikla [5 questions for Jan Šikl], Film 1996 14.1-15.11. s.35.

9 Foll, s. VIII.

10 Jan Jaroš (1996) Slibný debut Petra Václava [The Promising Debut of Petr Václav], Reflex, 49, p. 26.

11 Eva Kucová (1995) Chytilová žádala radnici o peníze na film pro kolegu [Chytilová Asked the Town Hall for Money for a Film by Her Colleague], MF Dnes, 4.10.1995, 1.VI No 232.

12 In the original, the word used is cikáné, which is consonant with the word for puppy - štěně.

13 Večernik, Jeden z Marianů [One of the Marians], Praha, 20.02.1997, s. 13.

14 Alena Prokopová (1997) Marian -př́iběh o tíze osudu [Marian - The Story of the Weight of Fate], Lidové noviny, 15.01.1997, s. 30.

15 Jaroš, p. 26.

16 Even in 2011, the report of the European Roma Rights Centre concerning residential care for Romani children was titled "Life Sentence," although the content and conclusions were not so dramatic. It mainly attacked the discontinuity among different stages of social intervention with Romani families.

17 Pavelčíková (2004) Romové v českých zemích v letech 1945-1989 [Roma in the Czech Lands, 1945-1989], Praha, Úřad, p. 9.

18 Ibid, pp. 134, 135.

19 Nina Pavelčíková is a historian from the University of Ostrava, who has gained a reputation as one of the key experts concerning the history of Roma.

20 Ibid, p. 136.

21 Ibid, p. 104.

22 Cynthia Levine-Rasky (2002) Working through Whiteness: International Perspectives, Albany, State University of New York Press, p. 16.

23 Probably, the most persistent echo of pathologizing Roma is the series of recent psychological surveys among Romani and non-Romani parents aimed at elaborating the fundamental differences between their approaches to parenthood in order to explain the complications of the educational system through such differences. For instance, in the 2003 publication, Romové v české společnosti: jak se nám spolu žije jaké má naše soužití vyhlídky [The Roma in Czech Society: How Do We Live Together, What Are the Perspectives for Our Co-Existence, Pavel Navrátil [ed.] Praha, Portal], a collection of essays written by Czech psychologists, some experts compare Romani mothers with gardeners, while Czech mothers are like pot makers - because of either their passive or active role in raising children (pp. 106-107). Generally, all these experts emphasize the need to elaborate collective rather than individual specifics of Roma as different; because of their shared experience, their 
experiences were often labeled as spiritual dying or spiritual death, and the inability to maintain individuality due to such traumatic events as the Porajmos or socialist surveillance (p. 58).

24 Pavelč́́ková, p. 14.

25 Ibid, p. 13.

26 Ibid, p. 14.

27 Nira Yuval Davis (1997) Gender and Nation, London, Sage.

28 Levine-Rasky, p. 16.

29 Miranda Fricker (2007) Epistemic Injustice: Power \& the Ethics of Knowing, Oxford, UK, Oxford University Press, p. 154.

30 Wendy Brown (1997) The Impossibility of Women's Studies, A Journal of Feminist Cultural Studies, 9, 3, pp. 79-101, 87.

31 Nira Yuval Davis (2010) Theorizing Identity: Beyond the 'Us' and 'Them' Dichotomy, Patterns of Prejudice, 44, 3, pp. 261-280.

32 Wendy Brown (2005) Edgework: Critical Essays on Knowledge and Politics, Princeton, NJ and Oxford, Princeton University Press, p. 32.

33 Ibid.

34 Julia Sardelić (2018) In and Out from the European Margins: Reshuffling Mobilities and Legal Statuses of Romani Minorities between the Post-Yugoslav Space and the European Union, Social Identities, 24, 4, pp. 489-504, 491.

35 Ibid, p. 492.

1 Jörn Rüsen (1997) Historical Narration: Foundation, Types, Reason, History and Theory, 26, 4, pp. 87-97.

2 Cornel West (1982) A Genealogy of Modern Racism, in Cornel West (ed.) Prophecy Deliverance! Towards an Afro-American Revolutionary Christianity, Philadelphia, PA, Westminster Press, pp. 47-68, 53-54.

3 For example, the conference "Romové a majorita: k výchově zdravých vztahů mezi lidmi" ["Roma and the Majority: Towards Cultivating Healthy Relationships Among People"], patronized by Jarosláv Balviín, one of the most influential historians of Czech education, held in Kladno in December 1996, was targeted at equipping teachers in special schools with new competencies for working with Romani students.

4 Rüsen, p. 89.

5 Celia Donert (2017) The Rights of the Roma: The Struggle for Citizenship in Postwar Czechoslovakia, Cambridge, UK, Cambridge University Press.

6 Rüsen, p. 90.

7 Nira Yuval Davis (2010) Theorizing Identity: Beyond the 'Us' and 'Them' Dichotomy, Patterns of Prejudice, 44, 3, pp. 261-280, 266.

8 Györgz Csepeli and Dávid Simon (2004) Construction of Roma Identity in Eastern and Central Europe: Perception and Self-Identification, Journal of Ethnic and Migration Studies, 30, 1, pp. 129-150, 132.

9 Věra Sokolová (2008) Cultural Politics of Ethnicity: Discourses on the Roma in Communist Czechoslovakia, Stuttgart, Ibidem-Verlag.

10 The casting of both films reflected the intention of the film director to make the films attractive to the audience. In Kdo se boji utiká, the most popular actors of that period were recruited. Radikální rez employed non-professional Romani actors together with popular Czech actors.

11 Zuzana Mojžišová (2014) Premýšlanie o filmových Rómoch [Thinking About the Roma in Films], Bratislava, Vysoká škola múzických umení Braislava, Filmová a televízna fakulta.

12 It is reasonable to mention Czech films that included Roma in the narration, such as Dobré svetlo [A Good Light, Karel Kachyňa, 1986] and Skalpel, prosím [Scalpel, Please, Jiři Svoboda, 1985], which both introduced Roma as supporting characters in a positive manner. 
13 Sokolová, p. 49.

14 Ibid, p. 66.

15 West, p. 49.

16 Sokolová, p. 103.

17 Ibid.

18 Michal Frankl and Miloslav Szabó (2015) Budování státu bez antisemitismu? Násilí, diskurz loajality a vznik Československa [Building the State Without Anti-Semitism? Violence, Discourse of Loyalty and the Appearance of Czechoslovakia], Praha, Nakladatelství Lidové noviny, p. 306.

19 Davis, p. 268.

20 Roy Bhaskar (2005) The Possibility of Naturalism: A Philosophical Critique of the Contemporary Human Sciences, London, Routledge, p. 41.

21 Ibid, p. 36, emphasis ours.

22 Muriel Blaive (2001) Promarněná přiležitost. Československo a rok 1956 [A Missed Opportunity: Czechoslovakia and the Year 1956], Praha, Prostor.

23 Martin Schulze Wessel (2018) Pražské jaro: Průlom do nového světu [Prague Spring: Breakthrough into a New World], Prague, ARGO.

24 Pavel Kolář and Michal Pullmann (2016) Co byla normalizace? Studie o pozdním socialismu [What was Normalization? Studies of Late Socialism], Praha, Nakladatelství Lidové noviny; Michal Pullmann (2011) Konec experimentu. Prestavba a pád komunismu v Československu. [The End of the Experiment: The Transformation and Crush of Communism in Czechoslovakia], Praha, Scriptorium.

25 Rüsen, p. 92.

26 Kolář and Pullmann, pp. 16-17.

27 Donert, p. 16.

28 Matěj Spurný (2011) Nejsou jako my: Česká společnost a menšiny v pohraniči (19451960) [They Are Not Like We Are: Czech Society and Minorities in the Border Zone (1945-1960)], Praha, Antikomplex, p. 281.

29 The book was published in English: Matěj Spurný (2019) Making the Most of Tomorrow: A Laboratory of Socialist Modernity in Czechoslovakia, Prague, Carolinum.

30 Sandra Harding (1997) Is Modern Science an Ethnoscience? Rethinking Epistemological Assumptions, in Emmanuel Chukwudi Eze (ed.) Postcolonial African Philosophy: A Critical Reader, Cambridge, MA: Blackwell Publishing Ltd., pp. 45-70, 54.

31 Spurný (2011), p. 248.

32 Ibid, pp. 240, 246.

33 In 2009, Barbora Šebová defended her masters thesis, "Škola Míru” v Květušíně 19501954 (a její pokračování na Dobré Vodě u Prachatic) - kritická reflexe v historickém kontextu 50 ["The School of Peace" in Květušín 1950-1954 (and its Continuation at Dobrá Voda u Prachatic) - a Critical Reflection on the Historical Context of the 1950s], which revealed the consistent practice of educators to hide the letters sent by parents from their children. Diplomová práce, Filozofická fakulta Univerzity Karlovy v Praze, Ústav jižní a centrální Asie Seminář romistiky.

34 Spurný (2011), p. 263.

35 Tomáš Kudrna (2015) Zatajené dopisy [Suppressed Letters] production of Studio OmeU D.

36 Jaroslav Balvín (2016) Etika učitele jako zápas [The Ethics of the Teacher as a Fight], Speciálni pedagogika, 26, 1, pp. 60-74.

37 Ibid, p. 66.

38 Rüsen, p. 92.

39 Kateřina Nedbálková and Kateřina Sidiropulu Janků (eds.) (2015) Doing Research, Making Science: The Memory of Roma Workers, Brno, Masaryk University, p. 27.

40 Kateřina Sidiropulu Janků (2015) Khatar san? Jak slovenšti Romové přišli do českých zemí za prací a co se dělo potom (katalog $k$ výstavě) [Khatar San? How Slovak Roma 
Came to the Czech Lands for Work and What Happened Next (Exhibition Catalog)], Brno: Masarykova univerzita, p. 12.

41 Lenka Jandáková (2015) Zatajené dopisy: Dokument o experimentu s romskými dètmi [SuppressedLetters:DocumentaryabouttheExperimentwithRomaniChildren], available online at www.romea.cz/cz/kultura/film/zatajene-dopisy-material-pro-dilnu-lidskosti.

42 Kateřina Sidiropulu Janků (2013) Marginalizovaní pamětníci, marginalizované vzpominky. Romští dělníci vzpominají na přichod do českých zemí za prací po druhé světové válce [Marginalizing Narrators, Marginalized Memories: Roma Workers Remember Their Arrival to the Czech Lands for Jobs after World War II], in Petr Bednařík, Blanka Soukopová and Helena Nosková (eds.) Pamět' - Národ-Menšiny Marginalizace - Identity I, Praha, Kosmas, pp. 143-153, 148.

43 Šebová, pp. 101-102.

44 Sidiropulu Janků, p. 147.

45 For example, Sidiropulu Janků stresses her intention to avoid any affiliation with labeling the history of Roma as a "cultural holocaust."

1 Nancy Ley Stepan (1986) Race and Gender: The Role of Analogy in Science, Isis, 77, 2, pp. 261-277.

2 Wim Willems (1997) In Search of the True Gypsies: From Enlightenment to Final Solution, London, Routledge, pp. 36-37.

3 Katrin Ufen (1996) Aus Zigeuner Menschen machen. Heinrich Moritz Gottlieb Grellmann und das Zigeunerbild der Aufklärung [Constructing Gipsies: Heinrich Moritz Gottlieb Grellmann and the Image of Gipsies during the Enlightenment], in Wulf D. Hund (ed.) Zigeuner: Geschichte und Struktur einer rassistischen Konstruktion [Gipsies: The History and Structure of One Racist Framework], Duisburg, DISS, pp. 67-90.

4 Willems, p. 40.

5 Nicholas Saul (2007) Gypsies and Orientalism in German Literature and Anthropology of the Long Nineteenth Century, London, Legenda, p. 6.

6 Marion Bonnilo (2000) Zigeunerpolitik im Deutschen Kaiserreich 1871-1918 [Gypsy Politics in the German Empire 1871-1918], Frankfurt um Mein: Peter Lang, p. 19.

7 Heinrich Moritz Gottlieb Grellmann (1807) Dissertation on the Gipseys: Representing Their Manner of Life, Occupations and Trades, Marriages and Education, Sickness, Death and Burials, Religion, Sciences, Art, London, William Ballintine, p. 66.

8 Viviana A. Zelizer (1985). Pricing the Priceless Child, New York: Basic Books, Inc.; Nancy Folbre (2008) Valuing Children: Rethinking the Economics of the Family, Cambridge, MA, Harvard University Press.

9 Shulamith Shahar (2017) Religious, Vagabonds, and Gypsies in Early Modern Europe, available online at https://brewminate.com/religious-vagabonds-and-gypsies-in-earlymodern-europe/.

10 Grellmann 12, emphasis in original.

11 Philippe Descola (2005) Beyond Nature and Culture, Radcliffe-Brown Lecture in Social Anthropology, available online at http://citeseerx.ist.psu.edu/viewdoc/downlo ad?doi $=10.1 .1 .470 .4920 \&$ rep $=$ rep1\&type $=$ pdf.

12 Grellmann, p. 31.

13 Ibid, pp. 13-14.

14 Ibid.

15 Ibid.

16 Ibid, p. 12.

17 Ibid, p. 9.

18 Ibid.

19 Ibid.

20 Ibid, p. 14.

21 Nathan Ron (2018) Erasmus' Ethnological Hierarchy of Peoples and Races, History of European Ideas, 44, 8, pp. 1063-1075, 1064. 
22 Ibid, p. 1065.

23 Grellmann, p. 95.

24 Ibid.

25 Justin Smith (1997) Nature, Human Nature and Human Difference Race in Early Modern Philosophy, Princeton, NJ, Princeton University Press, p. 53.

26 Grellmann, p. 99.

27 Ibid, p. 100.

28 Panikos Panayi (2000) Ethnic Minorities in 19th and 20th Century Germany: Jews, Gypsies, Poles, Turks and Others, New York, Routledge.

29 Karl von Heister (1842) Ethnographische und geschichtliche Notizen über die Zigeuner [Ethnographic and Historical Comments about the Gypsies], Königsberg, Verlagsort, pp. 146-147.

30 Londa Schiebinger (1993) Nature's Body: Gender in the Making of Modern Science, New Brunswick, NJ, Rutgers University Press.

31 Smith, p. 116.

32 Ibid, p. 124.

33 Grellmann, p. 11.

34 Steve Fenton (2003) Ethnicity, Malden, MA, Polity Press, p. 2.

35 Sara Ahmed (2007) Phenomenology of Whiteness, Feminist Studies, 8, 2, pp. 149-168, 154.

36 Ibid.

37 Grellmann, p. 34.

38 Ibid.

39 Ibid, p. 65.

40 Ibid, p. 46.

41 Ibid.

42 Ibid, p. 66.

43 Ibid, emphasis in original.

44 Ibid, p. 12.

45 Willems, p. 209.

46 Grellmann, p. 16.

47 Ibid.

48 Ibid, p. 25.

49 Ibid.

50 Ibid, p. 26.

51 Jennie Jacobs Kronenfeld (2006) Gender and Health Status, in Janet Saltzman Chafetz (ed.) Handbook of the Sociology of Gender, Houston, TX, Springer University of Houston, pp. 459-481, 461.

52 Grellmann, p. 104.

53 Ibid.

54 Ibid.

55 Ibid, p. 106.

56 Ibid.

57 Stepan, p. 264.

58 Grellmann, p. 101.

59 Ibid, p. 58.

60 Ibid.

61 David Theo Goldberg (2004) The End(s) of Race, Postcolonial Studies, 7, 2, pp. 211-230, 213.

62 In line with Bauman's concept of liquid modernity, the idea of liquid racism sheds light on combining overt racism with cultural signifiers that are not necessarily racist into powerful structures of racist thinking, which are difficult to negate. 
63 Karl Ritter von Scherzer (1873) Smyrna: mit besonderer Rücksicht auf die geographischen, wirthschaftlichen und intellectuellen verhältnisse von Vorder-Kleinasien [Smyrna: With Special Attention to the Geographical, Economic and Intellectual Conditions of Middle East Asia], Wien, Holder, p. 68.

64 Heister, p. 18.

65 Ibid, p. 19.

66 Alexandros Geōrgious Paspatēs (1870) Études sur les Tchinghianés ou Bohémiens de l'Empire Ottoman [Studies on the Gypsies or Bohemians of the Ottoman Empire], Constantinople, Antoine Koroméla, p. X.

67 Viktor Lebzelter (1922) Anthropologische Untersuchungen an serbischen Zigeunern [Anthropological studies on Serbian gypsies], in Mitteilungen der Anthropologischen Gesellschaft in Wien [News of the Anthropological Society in Vienna], Band 52, Wien, Im Selbstverlage der Gesellschaft, pp. 23-42, 26.

1 Marij Avčin (1913-1995) was a prominent physician, who, while simultaneously participating in the survey of Roma, had a fellowship in Denmark for studying genetics and social pediatrics.

2 The massive multidisciplinary measurement of Roma between 1960 and 1961 was organized by an interdepartmental team of Slovenian scholars and financially supported by the foundation of Boris Kidrič, which operated between 1953 and 1970, and aimed at elaborating the natural sciences in Slovenia.

3 Marij Avčin (1969) Gypsy Isolates in Slovenia, Journal of Biosocial Sciences, 1, pp. 221-233, 225.

4 The data concerning Roma in France were provided within the Human Adaptability Program (HAP), continued in the 1960s as the International Biological Program (IBP), the interdisciplinary network targeted with charting human biological variation around the world.

5 Brigitte Fuchs (2003) Rasse, Volk, Geschlecht Antropologische Diskurse in Österreich 1850-1960 [Race, People, Gender: Anthropological Discourses in Austria between 1850 and1960], Frankfurt and New York, Campus Verlag.

6 Andrew Wells (2010) Race Fixing: Improvement and Race in Eighteenth-Century Britain, History of European Ideas, 36, 1, pp. 134-138, 135.

7 Ibid.

8 Eugene Fischer (1961[1913]) Die Rehobother Bastards und das Bastardierungsproblem beim Menschen [The Rehoboth Bastards and the Problem of Miscegenation among Humans], Graz, Adeva.

9 Fuchs (2003), p. 160.

10 David Theo Goldberg (2004) The End(s) of Race Postcolonial Studies, 7, 2, pp. 211-230, 212.

11 Adam Kuper (2019) Civilization, Culture, and Race: Anthropology in the Nineteenth Century, in Warren Breckman and Peter Gordon (eds.) The Cambridge History of Modern European Thought, Cambridge, Cambridge University Press, pp. 398-421.

12 Wells, p. 136.

13 Fuchs (2003), p. 64.

14 Ibid, pp. 61-62.

15 Brigitte Fuchs (2011) Orientalizing Disease: Austro-Hungarian Policies of "Race," Gender and Hygiene in Bosnia and Herzegovina, 1874-1914, in Christian Promitzer, Sevasti Troumpeta and Marius Turda (eds.). Health, Hygiene, and Eugenics in Southeastern Europe to 1945, Budapest, CEU Press, pp. 57-85, 63.

16 Frank Spenser (ed.) (1997) History of Physical Anthropology, Vol. 2, New York and London, Garland Publishing, p. 110.

17 Fuchs (2003), pp. 121-122.

18 For a more in-depth view on the interrogation between race science and folk racism, see Chris Manias (2013) Race, Science and the Nation: Reconstructing the Ancient 
Past in Britain, France and Germany, 1800-1914, London and New York, Taylor \& Francis.

19 Jean-Christophe Coffin (1992) Le théme de la degénerescence de la race autour de 1860 [The Theme of the Degeneracy of the Races in the1860s], History of European Ideas, 15, 4-6, pp. 727-732.

20 Eve Rosenhaft (2008) Black Germans, in Prem Poddar, Rajeev Patke and Lars Jensen (eds.) Historical Companion to Postcolonial Literatures: Continental Europe and its Colonies, Edinburgh: Edinburgh University Press, pp. 211-212.

21 Andrew D. Evans (2010) Science Behind the Lines: The Effects of World War I on Anthropology in Germany, in Reinhard Johler, Christian Marchetti and Monique Scheer (eds.) Doing Anthropology in Wartime and War Zones, Bielefeld, Transcript Histoire, pp. 99-122, 110.

22 John Beddoe (1885) The Races of Britain: A Contribution to the Anthropology of Western Europe, Bristol, Arrowsmith.

23 John Beddoe (1870) The Stature and Bulk of Man in the British Isles, London, Asher and Co.

24 Fuchs (2003).

25 Rudolf Virchow (1874) Die ursprüngliche Bevölkerung Deutschlands und Europas [The Native Population of Germany and Europe], in Die vierte allgemeine Versammlung der deutschen Gesellschaft für Anthropologie, Ethnologie und Urgeschichte zu Wiesbaden am 15. Bis 17. September 1873 [The Fourth General Assembly of the German Society for Anthropology, Ethnology and Prehistory in Wiesbaden, September 5-17, 1873], in Nach stenographischen Aufzeichnungen redigit von Dr. A. v. Frantzius in Heidelberg [Edited and recorded by Dr. A. v. Frantzius in Heidelberg], Braunschweig, Friedrich Vieweg und Sohn, pp. 45-54, 45.

26 Ibid, p. 46.

27 Paul Weindling (1989) Health, Race, and German Politics Between National Unification and Nazism, 1870-1945, Cambridge, UK, Cambridge University Press, p. 39.

28 Rudolf Virchow (1885) Gesammtbericht über die Statistik der Farbe der Augen, der Haare und der Haut Schulkinder in Deutschland. [General Report on the Statistics of the Color of the Eyes, Hair and Skin of Schoolchildren in Germany], in CorrespondenzBlatt der deutschen Gesellschaft für Antropologie, Etnologie und Urgeschichte. 16. Jahrgang. 1885 [Correspondence Sheet from the German Society for Anthropology, Ethnology and Prehistory, 16th century,1885], Redigirt von Professor Dr. Johannes Ranke in München [Edited by Professor Dr. Johannes Ranke in Munich], München, Akademische Buchdruckerei von F.Straub, pp. 89-100.

29 Andrew Zimmerman (1999) Anti-Semitism as Skill: Rudolf Virchow's Schulstatistik and the Racial Composition of Germany, Central European History, 32, 4, pp. 409-429, 419.

30 Ibid.

31 Ibid, p. 420.

32 Evans, p. 104.

33 Fuchs (2003), p. 159.

34 Ibid, p. 149.

35 Christopher M. Hutton (2005) Race and the Third Reich: Linguistics, Racial Anthropology and Genetics in the Dialectic of Volk, Cambridge, UK, Polity Press, p. 50.

36 Marsha L. Rozenblit (2005) Sustaining Austrian "National" Identity in Crisis: The Dilemma of the Jews in Habsburg Austria, 1914-1919, in Pieter M. Judson and Marsha L. Rozenblit (eds.) Constructing Nationalities in East Central Europe, New York and Oxford, Berghahn Books, pp. 178-191.

37 Zimmerman, p. 410.

38 Evans, p. 116.

39 Ibid, p. 119. 
40 For one of the consistent examples, see Werner Kümmel (1968) Rudolf Virchow und der Antisemitismus [Rudolf Virchow and Antisemitism], Medizinhistorisches Journal, 3, 3, pp. 165-179.

41 Goldberg, p. 213.

42 Andre Gingrich (2010) After the Great War: National Reconfigurations of Anthropology in Late Colonial Times, in Reinhard Johler, Christian Marchetti and Monique Scheer (eds.) Doing Anthropology in Wartime and War Zones, Bielefeld, Transcript Histoire, pp. 355-379, 365.

43 Ibid, p. 366.

44 Weindling, p. 59.

45 Robert K. Merton (1972) Insiders and Outsiders: A Chapter in the Sociology of Knowledge, American Journal of Sociology, 78, 1, pp. 9-47.

46 Slobodan Naumovic (1999) Identity Creator in Identity Crisis: Reflections on the Politics of the Serbian Ethnology, Anthropological Journal on European Cultures, 8, 2, pp. 39-128, 115 .

47 Ibid, pp. 102, 112.

48 Robert Young (2005) Colonial Desire: Hybridity in Theory, Culture and Race, London, Routledge.

49 Joseph Arthur de Gobineau (1915) Essay of the Inequality of Human Races 1851-1853, Translated by Adrian Collins, London, William Heinemann.

50 Ibid, p. 93.

51 Ibid, p. 87.

52 Steven Kale (2010) Gobineau, Racism, and Legitimism: A Royalist Heretic in Nineteenth-Century France, Modern Intellectual History, 7, 1, pp. 33-61, 59.

53 Fuchs (2003), p. 65.

54 Seymour Drescher (2001) From Slavery to Freedom: Comparative Studies in the Rise and Fall of Atlantic Slavery, New York, Palgrave, pp. 292-293.

55 Michael Lausberg (2009) Die Resonanz des gobinistischen Rassenbegriffs bei Wagner und Nietzsche [The Resonance of the Gobinist Concept of Race in Wagner and Nietzsche], Tabvlarasa, 38, available online at www.tabvlarasa.de/38/Lausberg.php.

56 Weindling, p. 97.

57 Christian Promitzer (2004) The South Slavs in the Austrian Imaginations: Serbs and Slovenes in the Changing View from German Nationalism to National Socialism, in Nancy Wingfield (ed.) Creating the Other: Ethnic Conflict and Nationalism in Habsburg Central Europe, New York and Oxford, Berghahn Books, pp. 183-216, 185.

58 Augustin Weisbach (1837-1914) born in Komotau (Chomutov), was a medical officer who introduced a new method of physical anthropology by measuring the military personnel of different nationalities and was one of the most prominent members of the Anthropologischen Gesellschaft in Wien (as vice-president between 1888 and 1894). Weisbach directly influenced the formation of physical anthropology in the region.

59 Evans, p. 115.

60 Promitzer, p. 208.

61 Evans.

62 Promitzer, p. 197.

63 "Undesirable aliens" was a concept disseminated among the U.S. public and racially minded scholars, concerning migrants from Latin America and Central Europe. In 1929, this concept was the basis for the Undesirable Aliens Act or Blease's Law.

64 Sandra Harding (2006) Science and Social Inequality: Feminist and Postcolonial Issues, Urbana and Chicago, University of Illinois Press, pp. 29-30.

65 Ibid.

66 Herbert Spencer Jennings (1923) Undesirable Aliens, The Survey 51, pp. 309-312, 364. 
67 Kimball Young (1922) Intelligence Tests of Certain Immigrant Groups, The Scientific Monthly, 15, 5, pp. 417-434, 432.

68 Kimball Young (1893-1972) was an influential American sociologist and psychologist, who led the American Sociological Association.

69 Madison Grant (1916) The Passing of the Great Race: Or, The Racial Basis of European History, New York, Charles Scribner's Sons, p. 16.

70 Young, p. 430.

71 Grant, p. lii.

72 Defining the Ottoman empire in terms of the Osmanian yoke became widely disseminated after the deliberation of Serbia and Bulgaria; e.g., the novel by Ivan Vazov, "Under the Yoke" ("Под игото"), published in 1893, was translated into several Slavic languages and remained popular until the middle of the 1950s.

73 Grant, p. 56.

74 Will Seymour Monroe (1863-1939), a famous U.S. educator, spent the last decade of the nineteenth century in Europe teaching at the universities of Germany and Netherlands and traveling around Europe to collect materials for his overview of various, mainly peripheral, European countries.

75 Will Monroe (1910) Bohemia and the Cechs: The History, People, Institutions and the Geography of the Kingdom, Together with Accounts of Moravia and Silesia, Boston, L.C. Page and Company, p. 157.

76 Ibid, p. 158.

77 Will Monroe (1907) Turkey and the Turks: The Lands, the People and the Institutions of the Ottoman Empire, Boston, L.C. Page and Company, p. 108.

78 Will Monroe (1914) Bulgaria and Her People: With an Account of the Balkan Wars, Macedonia, and the Macedonian Bulgars, Boston, The Page Company, p. 188.

79 Ibid, p. 97.

80 Monroe (1907), p. 90.

81 Will Monroe (1900) Comenius and the Beginnings of Educational Reform, New York, Charles Scribner's Sons.

82 Alexander Barder (2019) Scientific Racism, Race War and the Global Racial Imaginary, Third World Quarterly, 40, 2, pp. 207-223, 210.

83 Grant, p. 59.

84 Joseph Deniker (1913) The Races of Man: The Contemporary Science Series. An Outline of Anthropology and Ethnography, London, Walter Scott Publishing.

85 Josef Deniker (1852-1918) was born into a French family in Russian Astrakhan, and in 1876 , he escaped from Russia due to persecution for political activity and made a career as one of the most influential theorists of racial assimilationism.

86 Deniker, p. 126.

87 Ibid, p. 8.

88 Ibid, p. 325.

89 Virchow (1885), pp. 90, 95.

90 Deniker, p. 8.

91 Ibid, p. 345.

92 Ibid, p. 125.

93 Ibid, p. 111.

94 Ibid, p. 139.

95 Glück not only led the Department of Dermatovenerology in the central hospital in Sarajevo but also established a leprosarium that achieved international acceptance; more can be found in Tomasz Jacek Lis (2014) Polskie osadnictwo i Duchowieństwo w Bośni i Hercegowinie od 1984 do 1920 Roku [Polish settlement and the Clergy in Bosnia and Herzegovina between 1984 and 1920], Torun, Maria, pp. 77-81.

96 Fuchs (2003), p. 129. 
97 In 1888, Crown Prince Rudolf, during his visit to Sarajevo, stressed: "Our mission is to bring western culture to the Orient"; more in Diana Reynolds (2010) Cordileone Swords into Souvenirs: Bosnian Arts and Crafts under Habsburg Administration, in Reinhard Johler, Christian Marchetti and Monique Scheer (eds.) Doing Anthropology in Wartime and War Zones, Bielefeld, Transcript Histoire, pp. 169-189, 172.

98 Leopold Glück (1894) Skizzen ans der Volksmedicin und dem medicinisehen Aberglauben in Bosnien und der Hercegovina [Description of Folk Medicine and Medical Superstition in Bosnia and Hercegovina], in Wissenschaftliche Mitheilungen aus Bosnien and Hercegovina [Scientific News from Bosnia and Hercegovina], Vol. 2, Wien, S. Gerold Sohn, pp. 392-454, 398.

99 Reynolds, p. 171.

100 Ibid.

101 Leopold Glück (1894) Die Tätowirung der Haut bei den Katholiken Bosniens und der Herzegovina [Skin Tattooing among the Catholics of Bosnia and Herzegovina], in Wissenschaftliche Mitheilungen aus Bosnien and Hercegovina [Scientific News from Bosnia and Hercegovina], Vol. 2, Wien, S. Gerold Sohn, pp. 455-462.

102 Leopold Glück (1896) Beiträge zur physischen Anthropologie der Spaniolen [Contributions to the Physical Anthropology of Spaniolen], in Wissenschaftliche Mitheilungen aus Bosnien and Hercegovina [Scientific News from Bosnia and Hercegovina], Vol. 4, Wien, S. Gerold Sohn, pp. 587-592, 592.

103 Harding, pp. 41-42.

104 Srđan Tucić (1915) The Slav Nation, The Daily Telegraph War Books, 19, English translation by Fanny S. Copeland, London, Hodder and Stoughton, p. 13, as cited in Connie Robinson (2011) Yugoslavism in the Early Twentieth Century: The Politics of the Yugoslav Committee, in Dejan Djokić and James Ker-Lindsay (eds.) New Perspectives on Yugoslavia: Key Issues and Controversies, London and New York, Routledge, pp. 10-26, 18.

105 Linda Hutcheon (2006) A Theory of Adaptation, London and New York, Routledge, p. 7.

106 Victoria Shmidt (2020) Race science in Czechoslovakia: Serving Segregation in the Name of the Nation, Studies of History and Philosophy of Biological and Biomedical Sciences, 79.

107 George Lipsitz (2006) The Possessive Investment in Whiteness: How White People Profit from Identity Politics, Philadelphia, PA, Temple University Press, p. 146.

108 Letter of Will S Monroe to F. Čáda 16.02.1918 AAV Osobní fond Františka Čády, box 1 , SIG II b 1.

109 Stefan Kühl (1997) Die Internationale der Rassisten Aufstieg und Niedergang der internationalen Bewegung für Eugenik und Rassenhygiene im 20. Jahrhundert [Internationalism of the Rise and Fall of Intercountry Movement on Eugenics and Racial Hygiene], Frankfurt and New York, Campus Verlag, p. 71.

110 Bohumil Němec (1873-1966), a deputy in the Czechoslovak Senate between 1922 and 1929 and an active member of the Czechoslovak National Democratic Party (Československá národni demokracie) was one of the leaders of the eugenics movement in Czechoslovakia.

111 Bohumil Němec (1921) O individualitě v př́rodě [About individuality in nature], Vzdèlávací př́loha Národních listů, 20.11.1921, No. 319.

112 Hutcheon, p. 34.

113 Lubor Niederle (1865-1944) was a Czech historian and anthropologist who advanced the idea of Pan-Slavism and was world famous for his surveys concerning the origin of the Balkan people.

114 The letter of Aleš Hrdlička to Lubor Niederle Feb. 6 1919. AAV Fond Lubora Niederle karton 1. 
115 Ibid.

116 Josef Jařab (1995) Images of America in Eastern Europe, History of European Ideas, 20, 1-3, pp. 583-584.

117 The letter of Aleš Hrdlička to Lubor Niederle March, 181919 AAV Fond Lubora Niederle karton 1.

118 Karel Driml (1928) Strýček z Ameriky [Uncle from America], Choceň, Loutkář, p. 15.

119 Ibid.

120 Harding, p. 60.

121 Ibid, p. 47.

122 Saul (2007) directly characterizes the nineteenth century in German scholarship as "virtually a desert" in the cultural anthropology of "Gypsies," p. 7.

123 Karl Freiherrn Czörnig (1857) Ethnographie der Oesterreichischen monarchie [Ethnography of the Austrian Monarchy], Wien, K.-K. Hof-und staatsdruckerei, p. 24.

124 Monroe (1907), p. 113.

125 Fuchs (2003), p. 143.

126 Augustin Weisbach (1889) Die Zigeuner, Wien, Anthropologische Gesellschaft, p. 532.

127 Monroe (1907), p. 113.

128 Ibid.

129 Ibid, p. 114.

130 Viktor Lebzelter (1922) Anthropologische Untersuchungen an serbischen Zigeunern [Anthropological Studies on Serbian Gypsies], in Mitteilungen der Anthropologischen Gesellschaft in Wien [News of the Anthropological Society in Vienna], Band 52, Wien, Im Selbstverlage der Gesellschaft, pp. 23-42, 27.

131 Monroe (1914), p. 190.

132 Introducing the concept of "White Gypsies" should be seen in connection with the dissemination of the concept of "white Jews" brought forward to public debates in the early nineteenth century by such anti-Semites as Hartwig von Hundt-Radowsky, who labeled the many "enemies" of Germany as "white" or "hidden" Jews. Labeling those who were not seen as belonging to the white world, e.g., Jews or "Gypsies," sheds light on the increasing role of whiteness in racializing Europe during the last decades of nineteenth century.

133 Johann Heinrich Schwicker (1883) Die Zigeuner in Ungarn und Siebenbürgen [The Gypsies in Hungary and Transylvania], Wien, Prochazka.

134 Leopold Glück (1897) Zur physischen Anthropologie der Zigeuner in Bosnien und der Hergegovina: Die mohammedanischen Zigeuner [About the Physical Anthropology of Gypsies in Bosnia and Hercegovina: Muslim Gypsies], in Wissenschafliche Mitteilungen aus Bosnien und der Hercegovina [Scientific News from Bosnia and Hercegovina], Vol. 3, Wien, S. Gerold Sohn, pp. 403-433.

135 Ibid.

136 Lebzelter, p. 28.

137 Ibid, p. 24.

138 Ibid, p. 23.

139 Glück used the traditional division of human skull into three subgroups, Dolichocephaliclong-headed, Mesaticephalic - medium-headed or Brachycephalic - short-headed.

140 Glück (1897), p. 409.

141 Tihomir Đorđević (1903) Die Zigeuner in Serbien: ethnologische Forschungen [Gypsies in Serbia: Ethnologic Studies], Wien, Thalia, p. 3.

142 Ibid, p. 30.

143 Ibid.

144 Ibid, p. 25.

145 Ibid.

146 Ibid, p. 80.

147 Ibid, p. 21. 
148 Ibid, pp. 28-31.

149 Ibid, p. 31.

150 Ibid, p. 27.

151 Ibid, p. 28.

152 Ibid, p. 30.

153 Ibid, p. 29.

154 Ibid, p. 31.

155 Ibid, p. 8.

156 Tihomir Đorđević (1929) Rumanian Gypsies in Serbia, Journal of the Gypsy Lore Society, VIII, pp. 7-24.

157 Đorđević (1903), p. 50.

158 Lebzelter, p. 5.

159 Hutcheon, p. 275.

160 Merton, p. 36.

161 Eva Blome (2017) Fantasies of Mixture, Politics of Purity: Narratives of Miscegenation in Colonial Literature, Literary Primitivism and Theories of Race (1900-1933), in Lara Day and Oliver Haag (eds.) The Persistence of Race: Continuity and Change in Germany from the Wilhelmine Empire to National Socialism, New York, Begrhahn, pp. 44-64, 44.

162 Anna Laura Stoler (1997) Carnal Knowledge and Imperial Power: Gender, Race, and Morality in Colonial Asia, in Roger N. Lancaster and Micaela Di Leonardo (eds.) The Gender/Sexuality Reader: Culture, History, Political Economy, London and New York, Routledge, pp. 13-36, 14.

1 Eric Sunderland (1980) The Population Structure of the Romany Gypsies, in Michael H. Crawford and James H. Mielke (eds.) Current Developments in Anthropological Genetics: Ecology and Population Structure, New York and London, Plenum Press, pp. 125-138, 127.

2 The International Biological Program (IBP) was an interdisciplinary network targeted with charting human biological variation around the world. It started as the Human Adaptability Program (HAP) in the 1950s and continued into the 1960s. For a detailed analysis of this international project as a driving force in racializing Roma, see Chapter 8.

3 Sunderland, p. 128.

4 Ibid, pp. 132-133.

5 For example, this approach was also disseminated among Croatian anthropologists; see Nevenko Bartulin (2014) The Racial Idea in the Independent State of Croatia: Origins and Theory, Leiden, Brill.

6 Eszter Varsza (2017) "The (Final) Solution of the Gypsy-Question:" Continuities in Discourses about Roma in Hungary, 1940s - 1950s, Nationalities Papers, 45, 1, pp. 114-130, 115.

7 Ibid, p. 116.

8 John Perkins (1999) Continuity in Modern German history? The Treatment of Gypsies, Immigrants \& Minorities, 18, 1, pp. 62-82, 63.

9 Shannon L. Fogg (2009) The Politics of Everyday Life in Vichy France: Foreigners, Undesirables, and Strangers, Cambridge, UK, Cambridge University Press, pp. 87-89.

10 Pierre Piazza (2004) Histoire de la carte nationale d'identité [History of the National Identity Card], Paris: Odile Jacob.

11 Mohammad H. Gharaati (1996) Zigeunerverfolgung in Deutschland mit besonderer Berücksichtung der Zeit zwischen 1918-1945 [Gypsy Persecution in Germany, with Special Reference to the Period between 1918-1945], Marburg, Tectum Verlag.

12 Dopis policajného riaditele adm. Předmět: Úprava stihania cigánov 26.10.1921 [The Letter of the Police Office to Local Authorities, Subject: Surveillance of the Gypsies, Corrections], SaK Collections of Košicka župa 1923-1928 II.YV, Box 430, Folder 5766. 
13 Jan Selling (2017) The Obscured Story of the International Criminal Police Commission, Harry Söderman, and the Forgotten Context of Antiziganism, Scandinavian Journal of History, 42, 3, pp. 329-353.

14 Mathieu Deflem (2002) Policing World Society: Historical Foundations of International Police Cooperation, Oxford, Oxford University Press.

15 František Štampach (1931) Kulturní primitivismus a civilisace: Studie a př́klady o primitivních prvcích kulturních u Slovanů [Cultural Primitivism and Civilization: Studies and Examples of Primitive Grounds among Slavs], in Primitivni element kulturni v hospodárském okruhu [Primitive Grounds in the Realm of the Economy], Vol. 1, Brno, Josef Pacl v Strakonicích, p. 13.

16 Hermann Aichele (1911) Die Zigeunerfrage mit besonderer Berücksichtigung Württembergs [The Gypsy Issue considering Württemberg], Tübingen, Universität Tübingen, p. 22.

17 Josef Mareš (1947) Ze života cikánů [About the Life of Gypsies], Kriminalistika, 2, 9, pp. $181-185,185$.

18 Mareš was referring here to the practice by unwed mothers to pass their offspring to Roma.

19 Josef Mareš (1948) Nekteré zvyky a mravy cikánů [Some Habits and Behavioral Patterns of Gypsies], Kriminalistika, 3, 6-7, pp. 129-133, 130.

20 Josef Mareš (1947) Cikáni musí pracovat [Gypsies Must Work], Kriminalistika, 2, 1, pp. 33-37.

21 Sybil Milton (1998) Antechamber to Birkenau: The Zigeunerlager after 1933, in Michael Berenbaum and Abracham J. Peck (eds.) The Holocaust and History: The Known, the Unknown, the Disputed, and the Reexamined, Bloomington, Indiana University Press, pp. 387-400, 388.

22 Erika Thurner (1983) Nationalsozialismus und Zigeuner in Österreich [National Socialism and Gypsies in Austria], Wien, Geyer Edition.

23 Tobias Portschy (1938) Die Zieugenrfrage: Denkschrift des Landeshauptmannes für das Burgenland [The Gypsy Issue: Memorandum of the Governor for Burgenland], Eisenstadt, Burgenländische Landesbibliothek, 3827-B.

24 Ibid. Until the end of the 1970s, his position concerning the "Gypsy issue" remained influential, even after accusations of wartime collaboration, for which he served a jail sentence.

25 The main city of Eastern Slovakia, with a high share of Romani populations.

26 Minister Českoslovenslej republiky s plnou mocou pre správu Slovenska [Minister of the Czechoslovak Republic with Power of Attorney for the Administration of Slovakia] 11.07.1921 Opatřenia proti cigánom Bratislava 11.07.1921, SaK, Collections of Košicka župa 1923-1928 II.YV, Box 430, Folder 5766.

27 Úprava stíhania cigáňov [Surveillance of the Gypsies: Corrections], 1921-09-22, ibidem, folder Policejní ředitelství v Bratislavě [Police Department of Bratislava] SaK Collections of Košicka župa 1923-1928 II.YV, Box 430, Folder 5766.

28 Opatrenie proti cigánom [Measures Against the Gypsies], 1921-07-15, ibidem, folder Služnovský úrad v Ždani [Office of the Local Authority in Ždan] SaK Collections of Košicka župa 1923-1928 II.YV, Box 430, Folder 5766.

29 Victoria Shmidt (2019) The Politics of Surveillance in the Interwar Czechoslovak Periphery: The Role of Campaigns Against Infectious Diseases, Zeitschrift für Ostmitteleuropa-Forschung, 68, 1, pp. 29-56.

30 Stefan Sibolovský (1931) Hluchonemé deti cigánské [Deaf and Dumb Gypsy Children], in Čtvrtý sjezd pro výzkum ditěte V Bratislavě 25.-27. řijna 1930, Prague, Výbor pro pořádání sjezdů pro výzkum dítěte, pp. 445-448, 446.

31 Ibid.

32 Aichele, pp. 16, 90. 
33 Robert Gaupp (1925) Die Unfruchtbarmachung geistig und sittlich kranker und Minderwertiger [The Infertility of the Mentally and Morally Ill and Inferior], Berlin, Julius Springer Verlag. A rigorous exploration of the inception and further transfer of the stigma of the "bastard" is presented in Christine Kunst (2009) Kontinuitäten der Stigmatisierung von "Mischlingkindem" und "Farbigen" am Beispiel der "Rheinlandbastarde" [Continuities of the Stigmatization of "Mixed-Race Children" and "Colored People" Through the Example of the "Rhineland Bastard"], in Stefanie Westermann et al. (eds.) Medizin im Dienst der "Erbgesundheit": Beiträge zur Geschichte der Eugenik und "Rassenhygiene" [Medicine in the Service of "Hereditary Health": Contributions to the History of Eugenics and "Racial Hygiene”], Berlin, Lit Verlag Dr. W. Hopf, pp. 109-126.

34 Shmidt (2019) The Politics of Surveillance.

35 Karl Moravek (1939) Zur Rassenkunde der burgenländischen Zigeuner [Toward Racial Knowledge of the Burgenland Gypsies], Dissertation, Wien Universität.

36 Some of Štampach's important life milestones are explored in Victoria Shmidt (ed.) (2019) The Politics of Disability in Interwar and Socialist Czechoslovakia: Segregating in the Name of the Nation, Amsterdam: Amsterdam University Press, pp. $95-101$.

37 A rigorous biography of Robert Ritter is available from Tobias Joachim SchmidtDegenhard's (2012) Vermessen und Vernichten: der NS-"Zigeunerforscher" Robert Ritter [Measuring and Annihilating: The Nazi "Gypsy Researcher" Robert Ritter], Stuttgart, Steiner.

38 In his letters to Matiegka, Stampach complained about the workload at school, which was described as an obstacle to his research interests. Additionally, Ritter had to leave his first job after one year due to conflicts with superior colleagues.

39 Štampach used two different words for defining police, četnictvi, relevant to the Austro-Hungarian period, and policie, introduced after 1918.

40 Letter by Štampach to Matiegka, Plzen 21.08.1926 ANM. Osobní fond J. Matiegka, Korespondence osobní príijatá karton č. 9 i.č. 330-473.

41 Bohumil Němec (1928) Biologická politika [Biological Politics], Vzdělávací př́loha Národnich listü, 01.01.1928, 1, p. 1.

42 Schmidt-Degenhard, pp. 139-141.

43 Karola Fings (2013) A "Wannsee Conference" on the Extermination of the Gypsies? New Research Findings Regarding 15 January 1943 and the Auschwitz Decree, Dapim: Studies on the Holocaust, 27, 3, pp. 174-194.

44 Tellingly, one of the main arguments in favor of Ritter's acquittal was the mistrust of the testimonies provided by Roma, who continued to be seen as unreliable witnesses, in contrast to respectable physicians and researchers; see more in Schmidt-Degenhard, p. 233.

45 Ibid, p. 234.

46 Ibid, p. 78.

47 Jaroslav Sus (1961) Cikánská otázka v ČSSR [The Gypsy Issue in Czechoslovakia], Praha, Státní nakladatelství politické literatury, p. 23.

48 Robert Ritter (1937) Mitteleuropäische Zigeuner ein Volkstamm oder eine Mischlingspopulation? [Central European Gypsies: Is It a National Group or a Mixed Population Group?], Congrès International de la Population, Paris 1937, VIII, pp. 51-60, 60.

49 Štampach (1931) Kulturní primitivismus a civilisace, p. 87.

50 Ibid, p. 88.

51 Ibid, p. 96.

52 František Š̉ampach (1931) Základy národopisu cikánů v ČSR Praha [Essentials of the Ethnography of Gypsies in Czechoslovakia], Národopisná společnost československá, p. 3.

53 Ritter (1937) Mitteleuropäische Zigeuner, p. 60.

54 Štampach (1931) Základy národopisu cikánů, p. 2. 
55 Ritter (1937) Mitteleuropäische Zigeuner, p. 51.

56 Eva Justin (1943) Lebensschicksale artfremd erzogener Zigeunerkinder und ihrer Nachkommen [The Destiny of Gypsy Children Brought Up Out of Families and Observation Under Them], in Inaugural-Dissertation zur Erlangung des Doktorgrades, Berlin, der Friedrich-Wilhelms-Universität, p. 35.

57 Gerhard Stein (1940) Zur Physiologie und Anthropologie der Zigeuner [The Physiology and Anthropology of the Gypsies], Deutschland Zeitschrift für Ethnologie, 72, 1/3, pp. 74-114, 86 .

58 František Štampach (1929-1930) Základy národopisu cikánů v ČSR [Essentials of the Ethnography of Gypsies in Czechoslovakia], manuscript, AAV MÚA AV ČR Fond 306 Jiří Horák inv. č 2298, Karton 40, pp. 34-35.

59 Robert Ritter (1937) Ein Menschenschlag Erbärztliche und erbgeschichtliche Untersuchungen über die durch 10 Geschlechterfolgen erforschten Nachkommen von "Vagabunden, Jaunern und Räubern," [A Breed of People: A Eugenic and Genetic-Historical Study of Ten Generations of "Vagabonds, Prowling Thieves, and Robbers"], Leipzig, Georg Thieme, pp. 54-55.

60 Ibid, p. 24.

61 Paul Weindling stressed: "The eradication of alcoholism was regarded as the means of raising productivity, enhancing emotional stability and curing a broad range of social ills"; see Paul Weindling (1989) Health, Race, and German Politics Between National Unification and Nazism, 1870-1945, Cambridge, UK, Cambridge University Press, p. 71.

62 Ritter (1937) Ein Menschenschlag Erbärztliche, p. 21.

63 Ibid, p. 22.

64 Fings, pp. 189-190.

65 Justin, p. 194.

66 Ibid, p. 36.

67 Ibid, p. 51.

68 Ibid, p. 35.

69 Shmidt (2019) The Politics of Surveillance, p. 35.

70 Štampach, Letter to Matiegka 7.3.1933 ANM Osobní fond J. Matiegky, Korespondence osobní přijatá [Accepted Personal Correspondence], karton č. 9 i.č. 330-473, J. Matiegka.

71 In the 1930s, a second "Gypsy" school was established in Mukačevo, another region with a large share of the Romani population.

72 F. B. Steiner (1939) Gypsies in Trans-Carpathian Russia, Journal of the Gypsy Lore Society, 18, 2-3, pp. 57-60, 59.

73 Marie Nováková (1949) Cikáni v Užhorodě [Gypsies in Uzhgorod], Dissertation, Charles University, Prague.

74 Ibid.

75 Pavel Baloun (2018) Československá civilizační mise: asimilační praktiky vůči "cikánským" dětem v letech 1918-1942 [Czechoslovak Civilizing Mission: Assimilation Practices for "Gipsy" Children in the Years 1918-1942] Déjiny - teorie - kritika 15, 2, pp. 175-202, 188-189.

76 Steiner, p. 60.

77 Ibid.

78 František Štampach (1931) Tělesný a duševní vývoj cikánského dítěte [The Physical and Mental Development of a Gypsy Child], in Čtvrtý sjezd pro výzkum dítěte V Bratislavě 25.-27. řijna 1930, Prague, Výbor pro pořádání sjezdů pro výzkum dítěte, pp. 174-177, 177.

79 Ibid, p. 175. 
80 Olga Holub (1933) První cikánské děti v dívčí výchovné české zemské komise pro péči o mládež v Jilemnici [The First Gypsy Children Under the Care of the Regional Board of Care for Youth in Jilemnici], Úchylná mládež, IX, pp. 45-47.

81 Shmidt (2019) The Politics of Disability.

82 Justin, p. 35.

83 Ibid, p. 32.

84 Ibid, p. 32.

85 Ritter (1937) Ein Menschenschlag Erbärztliche, p. 21.

86 Justin, p. 50.

87 Stefan Kühl recognized the direct impact of such family surveys on German eugenics: "National Socialists enthusiastically adopted the stories of the Jukes and Kallikaks in order to legitimize their own sterilization program"; see Stefan Kühl (2002) The Nazi Connection: Eugenics, American Racism, and German National Socialism, Oxford, Oxford University Press, p. 41.

88 Justin, p. 37.

89 Ibid, p. 50.

90 Ibid, p. 49.

91 Ibid, p. 47.

92 Ibid, p. 33.

93 Ibid, p. 42.

94 Ibid, p. 54.

95 Ibid.

96 Ibid, p. 52.

97 Ibid, p. 49.

98 Ibid, p. 33.

99 Ibid.

100 Ibid.

101 Ibid, p. 52.

102 Ritter (1937) Mitteleuropaische Zigeuner, p. 52.

103 More about the role of Weltzel in Porajmos can be found in Eve Rosenhaft (2008) Exchanging Glances: Ambivalence in Twentieth-Century Photographs of German Sinti, Third Text, 22, 3, pp. 311-324.

104 Hanns Weltzel (1938) The Gypsies of Central Germany, Journal of the Gypsy Lore Society, 24, pp. 73-77, 73-74.

105 Ibid, p. 74.

106 Alexander Petrović (1940) Contributions to the Studies of the Serbian Gypsies, Journal of the Gypsy Lore Society, XIX, 1-2, p. 99.

107 Alexander Petrović (1940) Review on Les Migrations Humaines: etude de Vesprit migratoire [Human Migration: Study of the Migration Mind], Ragnard Numelin with preface de Edward Westermark, Paris, Payot, 1939, Journal of the Gypsy Lore Society, XIX, 1-2, pp. 53-57, 55.

108 Wouter Van Wijk (1948) A Classificatory Account of the Gypsies Mainly Based on Material Accumulated in the "Journal of the Gypsy Lore Society." Leiden, Eduard Ijdo Ltd, p. 250.

109 Ibid.

110 Ibid, p. 129.

111 Ibid, p. 250.

112 Ibid, p. 252.

113 Moravek, pp. 12-13.

114 Andrej Kotljarchuk (2016) Roma and Travellers in Sweden during World War II: Registration, Experts and Racial Cleansing Policy-Making in a Transnational Context, Working, Paper presented at the 2016 Nordic Conference on Romani Studies, Södertörn University, p. 6. 
115 Andrej Kotljarchuk (2019) State, Experts, and Roma: Historian Allan Etzler and Pseudo-Scientific Racism in Sweden, Scandinavian Journal of History, DOI: 10.1080/03468755.2019.1668476, p. 6.

116 Judith Okely (1983) The Traveler-Gypsies, Cambridge, UK, Cambridge University Press, p. 20.

117 Ibid, p. 17.

118 Ibid, pp. 19-20.

119 Varsza, p. 119.

120 Ibid, p. 126.

121 Helena Malá and Josef Klement (1980) Antropologie druhu Homo sapiens a variabilita současného lidstva [Anthropology of Homo Sapiens and the Variety of Contemporary Humans], Praha, Státní pedagogické nakladatelství, pp. 99-100.

122 Etienne Balibar and Immanuel Wallerstein (1997) Race, Nation, Class: Les identites ambigues, Paris, La Decouverte, p. 36.

123 Ibid.

1 Michael Stewart (1997) The Time of the Gypsies: Studies in the Ethnographic Imagination, Boulder, CO, Westview Press, p. 246.

2 Stewart's writings were recommended by influential donors such as the Soros Foundation, who elaborated the issue of educating Romani children within special schools, and reviews of his texts mainly stressed the unique and new option for looking at the situation from the position of Roma. For instance, Tone-Kristin Lone defined the study "as a well written ethnography of the way Gypsies think and feel about themselves and 'others,' and how they order their lives in relation to these beliefs" (Tone-Fristin Lone [1999] Lone on Stewart, "The Time of the Gypsies," available online at https://networks.h-net.org/node/21311/reviews/21573/ lone-stewart-time-gypsies).

3 Michael Stewart (2013) Roma and Gypsy "Ethnicity" as a Subject of Anthropological Inquiry, Annual Review of Anthropology, 42, pp. 415-432, 423.

4 Michael Stewart (2004) Remembering without Commemoration: The Mnemonics and Politics of Holocaust Memories among European Roma, The Journal of the Royal Anthropological Institute, 10, 3, pp. 561-582, 577.

5 Etienne Balibar (2005) Difference, Otherness, Exclusion, Parallax, 11, 1, pp. 19-34, 24.

6 Etienne Balibar and Immanuel Wallerstein (1997) Race, Nation, Class: Les identites Ambigues, Paris, La Decouverte, p. 18.

7 Stewart (2004), p. 275.

8 Michael Mack (2003) Anthropology as Memory: Elias Canetti's and Franz Baermann Steiner's Responses to the Shoah, Oxford, Oxford University Press, p. 31.

9 Ibid, p. 88.

10 For instance, Malinowski, one of the main apologists of functionalism, consistently differentiated the position of anthropologist and colonizer. Such clear differentiation between the "practical man" of the colonial administration and the "disinterested" anthropologist who only wanted to work out a scientifically justified view of "savage life" without mingling in the colonial context, is often seen as the absence of interest in undermining attitudes that help to justify colonialism. See Mack, p. 93.

11 Frédéric Max (1946) Le sort des Tsiganes dans les prisons et les camps de concentration de l'allemagne Hitlerienne [The Fate of Gypsies in the Prisons and Concentration Camps of Hitler's Germany], Journal of the Gypsy Lore Society, 25, 1-2, pp. 24-35, 31.

12 During World War II, the mass extermination of Roma in German-occupied territories occurred not only at the hands of Nazis but also by local authorities. The systematic genocide of Roma in Yugoslavia and in the Protectorate of Bohemia and Moravia was organized and implemented by locals; more in Michael Zimmermann (1996) Rassenutopie und Genozid: Die nationalsozialistische "Lösung der Zigeunerfrage [Racial Utopia and Genocide: The National Socialist "Solution to the Gypsy Question], Hamburg: Christians. 
13 Ibid, p. 33.

14 Ibid, p. 27.

15 Henriette Asséo (2005) L'avènement politique des Roms (Tsiganes) et le genocide. La construction mémorielle en Allemagne et en France [The Appearance of the Politics Concerning the Genocide of Roma (Gypsies): The Construction of Memories in Germany and France], Le Temps des medias, 2, 5, pp. 78-91.

16 Karola Fings (2013) A "Wannsee Conference" on the Extermination of the Gypsies? New Research Findings Regarding 15 January 1943 and the Auschwitz Decree, Dapim: Studies on the Holocaust, 27, 3, pp. 174-194, 183.

17 Matéo Maximoff (1946) Germany and the Gypsies: From the Gypsies Point of View, Journal of the Gypsy Lore Society, pp. 104-108.

18 Ibid, p. 105.

19 Hermann Arnold (1965) Die Zigeuner: Herkunft und Leben im deutschen Sprachgebiet [The Gypsies: Origin and Life in the German-Language Area], Olten und Freiburg im Breisgau, Walter-Verlag, p. 277.

20 Ibid, p. 268.

21 Tellingly, in the 1960s, this dichotomy was heavily criticized in the reflections of the Holocaust and the impact of long-term, anti-Jewish propaganda in Germany, e.g., Alexander Bein (1965) Der Judische Parasit: Bemerkungen zur Semantik der Judenfrage [The Jewish Parasite: Comments on the Semantics of the Jewish Question], Vierteljahrshefte für Zeitgeschichte, 13, 2, pp. 121-149.

22 Tobias Portschy (1938) Die Zieugenrfrage: Denkschrift des Landeshauptmannes für das Burgenland [The Gypsy Issue: Memorandum of the Governor for Burgenland], Eisenstadt, Burgenländische Landesbibliothek, 3827-B.

23 Kurt Pastenaci (1951) Diagnose unserer Zeit [Diagnosis of Our Time], Berlin, Dunker Humblot, p. 38. Pastenaci was a German writer and journalist who had received acclaim during the Third Reich period as the author of The National History of Germans as well as historic novels with strong nationalistic motives. After 1945, he continued his successful career as a researcher of comparative culture with a particular focus on East and West.

24 Frank Sparing (1997) Von der Rassenhygiene zur Humangenetik - Heinrich Schade [From Racial Hygiene to Human Genetics - Heinrich Schade], in Michael G. Esch (ed.) Die Medizinische Akademie Düsseldorf im Nationalsozialismus [The Medical Academy Düsseldorf under National Socialism], Essen, Klartext, pp. 341-363.

25 Nevenko Bartulin (2014) The Racial Idea in the Independent State of Croatia: Origins and Theory, Leiden, Brill, p. 179.

26 Heinrich Schade and Georgina Pilarić (1961) Antropologischer Bericht über Zigeuner in Jugoslawien, zugleich ein Beitrag zur Frage der Brachycephalisation [Anthropological Report on Gypsies in Yugoslavia, Also a Contribution to the Question of Brachycephalization], Homo, 12, 4, pp. 185-193.

27 UNESCO (1950) The Race Question, in UNESCO and its Programme, available online at https://unesdoc.unesco.org/ark:/48223/pf0000128291, pp. 1-10, 7.

28 Ibid.

29 Michelle Brattain (2007) Race, Racism, and Antiracism: UNESCO and the Politics of Presenting Science to the Postwar Public, The American Historical Review, 112, 5, pp. 1386-1413, 1395.

30 Accusations of racism remained among the main public discourses within Soviet propaganda against the United States.

31 Jaroslav Sus (1961) Cikánská otázka v ČSSR [The Gypsy Issue in Czechoslovakia], Praha, Státní nakladatelství politické literatury, p. 11.

32 Ibid, pp. 24-25.

33 M.S. Plisecky (ed.) (1957) Rasovaya problema i obschestvo [The Race Issue and Society], Moscow, Innostrannaya Literature. 
34 Jaroslav Suchý (1957) quoted in Helena Malá and Josef Klement (1980) Antropologie druhu Homo sapiens a variabilita současného lidstva [Anthropology of Homo sapiens and the Variability of Contemporary Humanity], Praha, Státní pedagogické nakladatelství, p. 117.

35 Jan Strup and Eva Bacíková (eds.) (1960) Zkušenosti z práce mezi cikánským obyvatelstvem 1. sborniček [The Experience of Working among Gypsies: First Part], Praha, Osvětový ústav v Praze [The Institute of Enlightenment], p. 3.

36 Ministerstvo školství [Ministry of Education] (1974) Předškolni a školni výchova cikánských dètí Dlohoudobá koncepce [Pre-School and School Education of Gypsy Children Long-Term Concept], Praha, Státní pedagogické nakladatelství.

37 Balibar and Wallerstein, p. 21.

38 Jane Schuch (2017) Negotiating the Limits of Upbringing, Education, and Racial Hygiene in Nazi Germany as Exemplified in the Study and Treatment of Sinti and Roma, Race, Ethnicity and Education, 20, 5, pp. 609-623.

39 One of the most visible traces is the formulation of a list of "asocial" families living in Prague by Josef Apetaur, child psychiatrist, in response to a request made by the principal physician of Prague, Viktor Kindermann; more in Victoria Shmidt (ed.) (2019) The Politics of Disability in Interwar and Socialist Czechoslovakia: In the Name of Segregation, Amsterdam, Amsterdam University Press, pp. 116-117.

40 More about lionization of the Czech race science can be found in Victoria Shmidt (2018) The Legacy of Eugenics in CEE Countries: The Limits and Options for Historical Consciousness, Working Papers of the Centre for Advanced Studies in Sofia, 10, pp. 1-53, 18-19.

41 Uwe Hossfeld and Michal Šimůnek (2008) Die Kooperation der Friedrich-SchillerUniversität Jena und der Deutschen Karls-Universität Prag im Bereich der "Rassenlehre," 1933-1945 [The Cooperation between the Friedrich Schiller University in Jena and the German Charles University in Prague in the Field of "Racial Studies," 1933-1945], Erfurt, Landeszentrale für politische Bildung Thüringen.

42 While the Institute of Social Anthropology and People's Biology at the Faculty of Philosophy (Institut für Sozialanthropologie und Volksbiologie an der Philosophischen Fakultät), under the supervision of Karl Valentin Müller, focused on the issue of the Germanization of the Czech population (more in Eduard Kubů [2004] "Die Bedeutung des deutschen Blutes im Tschechentum"). Der "wissenschaftspädagogische" Beitrag des Soziologen Karl Valentin Müller zur Lösung des Problems der Germanisierung Mitteleuropas [What German Blood Means for the Czech People: The "Scientific" Contribution of the Sociologist Karl Valentin Mülle Towards Solving the Problem of How to Germanize Central Europe], Bohemia 45, 1, pp. 93-114), Schultz conducted his own research targeted with tracing mixed Czech-German families (several boxes with the results of anthropometric measurement of the offspring of mixed Czech-German couples were revealed by the staff of the Museum of Man).

43 Jiří Malý (1939) Něco o cikánech [Something about Gypsies], Naši přirodou, III, pp. 197-198, no VIII, pp. 314-315, 198.

44 Paul Weindling (1989) Health, Race, and German Politics Between National Unification and Nazism, 1870-1945, Cambridge, UK, Cambridge University Press, p. 57.

45 Arnold (1967), p. 277.

46 František Štampach (1945) The Letter to the Faculty of Natural Sciences, Charles University, 18.07.1945 AUK Osobní fond Jíŕi Malého.

47 Jan Beneš (1974) The Letter to Jaroslav Suchý 12.02.1974, AUA, Personal archive of J. Beneš, Inv. č. 21, Masaryk University, Brno.

48 Marie Nováková (1969) Les Tyiganes D’Autrefois de la Tchécoslovaquie [Former Gypsies of Czechoslovakia], Anthropologie (1962-), 7, 2, pp. 41-43. 
49 Miroslav Dědič (1975) Cikánské dětí a mládež ve výchovně vzdělávacím procesu [Gypsy Children in the Educational Process], Pedagogika, 2, pp. 177-187, 178.

50 Name of village where the survey was conducted.

51 Jan Beneš: Undated, untitled document. AUA, Personal archive of Jan Beneš, Inv č. 21. The original orthography has been maintained.

52 The document should be dated between 1989 and 1990 - according to the event mentioned by Beneš - the exhibition of Rudolf Dzurko, an artist of Romani origin, organized in 1989. Also, in his correspondence with Harvard University's administration before his visit, Beneš offered this topic as a possible contribution.

53 In his curriculum vitae for submitting applications for international projects, Beneš described his major academic interests as follows: "Cultural, social and biological adaptability of ethnic minorities in Europe (Lusatian Serbs, Gypsies). Adaptability and variability of past and present populations. Some bioecological and cultural aspects of evolution of Man. Human ecology." Archive of the Institute of Anthropology, Faculty of Natural Sciences, Masaryk University, Personal archive of Jan Beneš Inv. č. 13, Box XXI.

54 The "Gypsy issue" as a topic for presentation was not approved, and, finally, Beneš made the presentation "The role of universities in Czechoslovakia's Velvet Revolution."

55 Beneš commented on the studies conducted by him and his colleagues in favor of demonstrating the ineducability of Roma in following way:

The data quoted here were established in schools for Gipsy children. They are attended by children from badly situated Gipsies. It cannot be excluded that Gipsy children from accultured families attending schools for the majority population exhibit different parameters. So far they are unknown.

(Jan Beneš: Undated, untitled document)

56 Ibid.

57 Viewing Roma as a self-isolated group was not exceptionally a Central European approach. In their report on the study among Roma living in Stockholm, Lars Beckman and John Tackman stressed:

The Swedish Gypsies appear to have been rather isolated from the Swedes as well as from other European Gypsy groups. Consanguineous marriages seemed to be rather frequent, for according to the census questionnaires 40 individuals (or about 10 per cent) were the offspring of cousin marriages. In 1913 more than 80 per cent of the Swedish Gypsies were illiterates. At present the number of Swedish Gypsies can be estimated to approximately 1000. Most families are settled, special schools for children and adults have been created and the Gypsy population is in the process of being assimilated into the Swedish society.

See Lars Beckman and John Tackman (1965) On the Anthropology of Swedish Gypsy Population, Hereditas, 53, 1, pp. 272-280, 272.

58 Tellingly, in his post-socialist writings, Beneš started to use the definition of ethnotransformation, "aiming at a gradual decline of ethnicity proper and, finally, at accepting the ethnographical features of the surrounding population" (Jan Beneš: Undated, untitled document).

59 Another important factor in reproducing the view on Roma as a self-isolated group was increasing interest in this explanatory scheme among Western scholars. In the 1950s, several surveys aimed at tracing the racial assimilation of African Americans to the white population established a negative attitude toward self-isolation among racially minded Western scholars; see, for example, the article by Bentley Glass and Ching Chun Li (1953) The Dynamic of Racial Intermixture - An Analysis Based on the American Negro, American Journal of Human Genetics, 5, 1, 1-20. The article was disseminated among Yugoslav scholars immediately after publishing. 
60 Marij Avčin (1969) Gypsy Isolates in Slovenia, Journal of Biosocial Sciences, 1, pp. 221-233, 222.

61 Letter of Zlata Dolinar to Božo Škerlj 17.VI.1961 AGA, Personal archive of Škerlj, Box 14.

62 Marijan Hovčar (1964) Die Verteilung der Blutgruppen bei einem Zigeunerisolat [The Distribution of Blood Groups in a Gypsy Isolate], Proceedings of Tenth Congress of International Society of Blood Transfusion, pp. 312-319.

63 Z. Dolinar, A. Pogačnik, B. Sever, and V. Siftir (1962) Izolati Ciganov in Kalvinistov v Prekmurju [Isolates of Gypsies and Calvinists in Prekmurje], Manuscript AGA, unsorted collection.

64 Helena Malá, Personal profile, AUK.

65 One of the first publications addressed a Western audience: Jaroslav Suchý and Helena Malá (1968) The Physical Features of Gypsy Youth, Rivist di Antropologia Roma, LVI, pp. 31-43.

66 Helena Malá (1956) The Letter to Škerlj 12.04.1956, AGA, Personal archive of Škerlj, Box 11.

67 Both Škerlj and Malý were doctoral students of Matiegka and they started their informal cooperation during the interwar period. Both were involved by Matiegkato in the campaign against Racial Hygiene and German race science in the mid-1930s. After the war, until the death of Malý, they exchanged new methods of anthropological measurement through letters. After the death of Malý, his wife and daughter continued regular communication with Škerlj until his death.

68 More can be found in Victoria Shmidt (2020) Race Science in Czechoslovakia: Serving Segregation in the Name of the Nation, Studies in History and Philosophy of Science Part C: Studies in History and Philosophy of Biological and Biomedical Sciences, 79.

69 On October 24, 1948, Vprašanja naših dni [Issues of our Days], the newspaper of the Communist Party in Slovenia, published a translation of Lysenko's speech "The Situation in Biological Science," delivered during the session of the Lenin All-Union Academy of Agricultural Sciences. Slovenian biologists and geneticists felt confident enough to provide a direct rebuff to communist pressure. Moreover, being a former prisoner in a Nazi concentration camp, Škerlj could not be accused of sympathizing with "racist science," the label ascribed by Lysenkoism to genetics. He chose the popular newspaper Osveta [Enlightenment] in order to attack Lysenkoism, publishing several articles in favor of genetics. His response to Soviet pressure aligned with his intention to deepen cooperation with Western science. He obtained long-term academic fellowships in several Western European centers of genetics and physical anthropology, including Harvard University in 1952, the Royal Anthropological Institute of Great Britain and Ireland in 1953 and the Anatomical Institute in Lund in 1956.

70 William Dejong-Lambert and Nikolai Krementsov (2012) On Labels and Issues: The Lysenko Controversy and the Cold War, Journal of the History of Biology, 45, 3, pp. 373-388, 385.

71 Jirásek was referring to the anthropological communities in Prague, Brno and Bratislava, which had maintained strongly contested relations since the interwar period.

72 A. Jirásek (1960) Dopis Jiráska Suchemu 18.1.1960 [Letter of Jirásek to Suchý], AAV, Osobní fond Jirásek Arnold, Sig. II.b Inv.

73 In the early 1970s, when the political tension between different Yugoslav nations reached a peak, scholars were asked to adopt international, anti-racist rhetoric for devaluating the national aspirations of different Yugoslav nations as racially determined. See Zlata Dolinar and Anton Pogačnik (eds.) (1972) Rasna Diskriminacija i oblici borbe za njeno suzbijanje [Race Discrimination and the Forms of Combating It], in Referati za naučni skup Sveska II [Papers for the Scientific Conference Volume II], Sarajevo, Univerzitet u Sarajevu. 
74 For instance, Slovenian anthropologist Zlata Dolinar, the successor to Božo Škerlj, published the survey, based upon data collected by Croatian anthropologists; see Zlata Dolinar (1963) Prispevek k dednosti spastične familiarne paralize na otoku Krku [A Contribution to the Problem of Inheritance of the Spastic Familiar Paralysis on the Island of Krk], Biološki vestnik XI Biološka sekcija prirodoslovnega društva Ljubljana [Biological Bulletin XI Biological Section of the Natural History Society of Ljubljana], Ljubljana, Tiskarna Toneta Tomsiča.

75 Miloš Macura provided a rigorous comparative context concerning Central European demographic policy in his 1974 article "Population Policies in Socialist Countries of Europe" Population Studies, 28, 3, pp. 369-379. For a comprehensive historical overview of demographic policy in Yugoslavia, see Dušan Breznik (1982) The Dynamics of Population in Yugoslavia Eastern European Economics, 20, 3/4, pp. 215-249.

76 World Population Conference Belgrade 30 August-September 10 1965, Opening Statement Philippe de Seynes, Under Secretary for Economic and Social Affairs, p. 2.

77 In 1966, and for next six years, Miloš Macura, who led the Department of Population Studies at the Serbian Academy of Arts and Sciences and organized the UN Conference in Belgrade, became the Director of the Population Division.

78 Milos Macura (1986) What Role for the UN in Population? European Journal of Population/Revue Européenne de Démographie, 2, 1, pp. 1-4.

79 World Population Conference, Belgrade, 1965.

80 Ibid.

81 Helena Malá (1984) Výchova, vzdělávání a biologický vývoj cikánských dètí a mládeže $v \check{C} S R$ [Education, Upbringing and Biological Growth of Gypsy Children in Czechoslovakia], Praha, Univerzita Karlova, p. 41.

82 Svatopluk Cenek (1970) Návrh dlouchodobé koncepce školní výchovy cikánských dětí [Draft of the Long-Term Conception for the Education of Gypsy Children], Výzkumný ústav pedagogický v Praze. Arhiv Muzea romské kultury, Osobní fond M.Dědiče, Box 26.

83 Hermann Arnold (1967) Zur Frage der Fruchtbarkeit von Zigeunern, Zigeuner Mischlinsgruppen und anderen sozialen Isolaten. [About the Issue of Fertility among Gypsies, Gypsy Mixes and Other Social Isolates], Homo, 18, pp. 85-90.

84 Balibar and Wallerstein, p. 19.

85 World Population Conference, Belgrade, 1965, p. 6.

86 H. Bentley Glass (1954) Genetic Aspects of Adaptability, Genetics and the Inheritance of Integrated Neurological and Psychiatric Patterns, XXXIII, pp. 367-377, 367.

87 Aleš Hrdlička was one of the first promoters of adaptability as a possible mainstream for the sustainable development of physical anthropology; more in Aleš Hrdlička (1918) Physical Anthropology: Its Scope and Aims; Its History and Present Status in America, American Journal of Physical Anthropology, 1, pp. 3-23.

88 William Leonard (2018) Centennial Perspective on Human Adaptability, American Journal of Physical Anthropology, 165, 4, pp. 813-833.

89 Paul Weiss (1949) The Biological Basis of Adaptation, in John Romano (ed.) Adaptation, Ithaca, NY, Cornell University Press, pp. 1-22.

90 Glass, p. 368.

91 Ibid.

92 Ibid, p. 369.

93 U.S. Participation in the International Biological Program, Report No. 1974, p. 69.

94 Ibid, p. 73.

95 Ibid, p. 76.

96 Ibid.

97 Ibid, p. 70.

98 Ibid, p. 82. 
99 Ibid, p. 74.

100 Ibid, p. 83.

101 Doubravka Olsakova (2018) The International Biological Program in Eastern Europe Science: Diplomacy, Comecon and the Beginnings of Ecology in Czechoslovakia, Environment and History, 24, 4, pp. 543-567.

102 Czechoslovak National Committee for the International Biological Program (1968) The Czechoslovak Contribution to the International Biological Program, Prague, Czechoslovak Academy of Science.

103 Shmidt (2020).

104 Helena Malá and Jaroslav Suchý (1970) The Anthropological Research on Gypsy Children and Youth in Czechoslovakia, Glasnik Antropološkog društva Jugoslavije, 7, pp. 39-61, 54.

105 Ibid.

106 Helena Malá (1973) Body Characteristics of New-Born Gypsies from Bohemia, Glasnik antropološkog društva Jugoslavije, 11, 1/2, pp. 53-55. Ten Romani children were described as shorter and lighter than their non-Romani peers.

107 U.S. Participation in the International Biological Program Report, No. 1974, p. 70.

108 Ibid, p. 73.

109 Under the auspices of the IBP, the Institute of Experimental Biology and Genetics at the Czechoslovak Academy of Science in Prague conducted independent research on the Eastern periphery aimed at estimating the genetic load in human populations and contributing to the knowledge of the latent genetic load. In the focus was the endogamy dating as far back as the eighteenth century in the mountainous part of East Slovakia. The following data were collected: personal data of couples, pedigree, duration of married life, place of residence as stated in the marriage register, outcomes of all pregnancies, whether abortion or a live birth, sex, age and parity of the children, whether living or dead, incidence of hereditary diseases and defects, and ABO blood group data. Two villages situated in East Slovakia were studied through collecting demographic data and blood analysis for inbreeding, ABO, MNS, Rh, Kell-celano, the Duffy blood group system, $\mathrm{Gm}$ and $\mathrm{Hp}$ blood serum system. The sample of consanguineous families was ascertained through the marriage registers of the Catholic and Orthodox Episcopal Churches and control families were selected in each of the visited villages.

110 Helena Malá and Jaroslav Suchý (1970) The Anthropological Research on Gypsy Children and Youth in Czechoslovakia, Glasnik Antropološkog društva Jugoslavije sveska, 7, pp. 39-61, 59-61.

111 Anton Pogačnik (1968) Antropološské in morfološske karakteristike ciganov v prekmurju [The Anthropological and Morphological Characteristics of Gypsies from the Prekmurje Region], Dissertation, Slovenska Akademija znanostiin umetnosti, Oddelek za prirodoslovne vede, Ljubljana, p. 7.

112 Ibid, p. 9.

113 Malá (1984), p. 5.

114 Pogačnik, p. 10.

115 U.S. Participation in the International Biological Program, Report No. 1974, p. 100.

116 Grammar and syntax presented as in original.

117 Jan Beneš (1970) Letter to A. Pogačnikovi 13.01.1970, AUA, Personal archive of J. Beneš, Inv. č. 21, Masaryk University. Brno.

118 Jan Beneš (1970) Letter to L. Beckman 29.01.1970, AUA, Personal archive of Beneš, Inv. č. 21, Masaryk University, Brno.

119 Beckman and Takman.

120 Pogačnik, p. 12.

121 Eric Sunderland (1930-2010), the Welsh anthropologist and geneticist, was the author of Genetic Variation in Britain (1973) and Genetic Markers in Welsh Gypsies (1977), published in the Journal of Medical Genetics, 14, 3, pp. 177-182. In 
his monograph Elements of Human and Social Geography: Some Anthropological Perspectives (Pergamon Press, 1973), Sunderland deepened the argument in favor of investigating "primitive" self-isolated groups:

[B]iological adaptability of humans is not as directly brought about as it is in other organisms since cultural factors obtrude in such a way as to stand between man and the full rigors of direct environmental pressures.... Perhaps the most direct interaction of man and the environmental factors most concerned [are] to be witnessed in simpler societies of the world.

(pp. 59-60)

122 Helena Malá (1970) Letter to Jan Beneš 13.03.1970, AUA, Personal archive of Beneš, Inv. č. 21, Masaryk University Brno.

123 U.S. Participation in the International Biological Program, Report No. 1974, p. 100.

124 Eric Sunderland (1980) The Population Structure of the Romany Gypsies, in Michael H. Crawford and James H. Mielke (eds.) Current Developments in Anthropological Genetics: Ecology and Population Structure, New York and London, Plenum Press, pp. 125-138, 127.

125 Jan Beneš (1974) Letter to J. Suchý 09.09.1974, AUA, Personal archive of Beneš, Inv. č. 21, Masaryk University Brno.

126 Anna Lorencová and Jan Beneš (1976) Industrial Population in Moravia (CSSR): A Study in Variability and Adaptability, Folia F.S.N U.J.EP. Brunensis, XVII, 5, pp. 1-137.

127 Balibar and Wallerstein, p. 19.

128 U.S. Participation in the International Biological Program, Report No. 1974, p. 84.

129 Malá and Klement, p. 95.

130 Ministerstvo školství [Ministry of Education] (1974) Předškolní a školní výchova cikánských dètí Dlohoudobá koncepce Státní pedagogické nakladatelství [Pre-School and School Education of Gypsy Children Long-Term Concept], Praha, Státní pedagogické nakladatelství, p. 11.

131 Helena Malá and Jaroslav Suchý (1976) Bodily Development of Gypsy SchoolChildren in Children's Homes, Folia Morphologica, XXIV, 2, pp. 197-198.

132 Malá (1984), p. 5.

133 Ibid, p. 35.

134 Ibid, p. 73.

135 Ministerstvo školství, p. 10.

136 Shmidt (ed.) (2019).

137 František Vavruška (1971) Dokumenty k boji proti kriminalitě mládeže [The Training Materials of the Institute for Retraining Educators for the Fight against Youth Criminality], p. 3-12, Krajský semináŕ k problémům delikvenci dětí a kriminality mládeže v Jihočeském kraji [Regional Workshop on the Issue of Delinquent Children and Criminal Youth in the South Czech Region] Sborník materiálu Krajská odborová rada Jihočeský krajský národní výbor KV ĊOS pracovníků školství a vědy [Regional Board of Workers in Education and Science] Krajský pedagogický ústav v Českých Budějovicích 1972 SOA in Třeboň. Krajský pedagogický ústav Kabinet speciální pedagogiky [The Collection of the Regional Pedagogical Institute, Subdivision of Special Education], Box 6.

138 The term "metodist" was adopted from the Soviet system of professional retraining for teachers; in the U.S.S.R., the centers in each region for retraining educators were named metodicheskie centry.

139 In the 1970s, Dědič established the Subdivision for Retraining the Educators Who Teach Roma Students (Cabinet pro výuku a výchovu cikánských dětí) within the Center for Educator Training in České Budějovice (Bohemia), and Štěpán - in Jičín 
(Moravia). Both operated as the key channels for connecting practitioners with experts until the end of socialist period.

140 Josef Štěpán (1976) Postavení cikánského mentálně retardovaného žáka v etnicky heterogenní skupině [The Status of the Mentally Retarded Gypsy Student in an Ethnically Heterogeneous Class] Zápis ze semináře, konaného ve dnech 12. a 13. listopadu 1976 v Brně na téma "Problémy výchovy cikánských dětí v dětských domovech a výchovných ústavech" [The Issues in Education of Gypsy Children in Children's Homes and Residential Care Institutions] Bulletin č. 29. Národní sdružení dětských domovi̊ FICE v ČSSR pp. 27-34, MRK, Personal archive of M. Dědiče, Box 26.

141 Subdivision of the education for Gypsy children (1972) Zpráva: Seminár̆ pro ředitele dětských domovi̊ a zvlaštních škol internatních Středočeského kraje [The Minutes: Workshop for the Principals of Children's Homes and Boarding Schools of the Central Bohemian Region] Krajský Pedagogcký ústav v Praze, 4.10.1972, SOA in Třeboň, The Collection of The Regional Pedagogical Institute, Subdivision of Education for Gypsy Children, Box 7.

142 Miroslav Dědič (1973) Zpráva o jednání na mateřské škole ve Strunkovicích nad Blanicí, které bylo uskutečněno dne 3.dubna 1973 [Report about the Negotiation at the Kindergarten in Strunkovici nad Blanicí, 03.04.1973] SOA in Třeboň, The Collection of The Regional Pedagogical Institute, Subdivision of Education for Gypsy children, Box 7.

143 An English summary and synopsis is available online at www.filmovyprehled.cz/en/ film/396166/my-friend-the-gipsy.

144 František Tichý (1896-1961) was a Czech artist who represented the Czech avantgarde; one of the main motifs was Roma and circuses.

145 Rick Altman (2008) A Theory of Narrative, New York, Columbia University Press, p. 104.

146 Ibid, p. 100.

147 Antonín Malina (1955) Můj přitel Fabian, Obrana lidu, 07.01.1955, p. 2.

148 Lidová demokracie (1955) Můj př́tel Fabian, 07.01.1955.

149 Altman, p. 123.

150 A synopsis is available online at www.filmovyprehled.cz/en/film/397528/who-isafraid-flees.

151 One of the delighted critics entitled his review "Jak učitelé nepřicházejí o iluze" ("How Do Teachers Not Lose Their Illusions"), which reproduced the title of the second part of Básníci: "Jak básníci přicházejí o iluze" ("How Poets Lose Their Illusions").

152 Pavel Jiras (1985) Interview with Dušan Klein, Kino, 6, 1985.

153 Altman, p. 104.

154 Ibid.

155 Ibid, 90.

156 Ibid.

157 Ibid, p. 125.

158 The premiere of the film took place in Krumlov, the town where Dědič and a few of his former students lived; they were invited to attend the premiere and to share their feelings after watching the film. Klein directly reproduced their reaction as an argument in favor of the film: "One of the students, who had become a special educator and defended her dissertation, shared her story that if there would be no 'Dad,' we would be unable even to write.” See Josef Řezač (1987) Hledání tolerance a porozumění Rozhovor s režisérem Dušanem Kleinem [Looking for Tolerance and Recognition with Film Director Dušan Klein], Film a doba, 6, pp. 303-308, 306.

159 Radikálni řez [A Radical Cut, 1983], a detective story about a murder, in which the investigation reveals prejudices against Roma, was the first film by Klein dedicated 
to the "Gypsy issue." A synopsis is available online at www.filmovyprehled.cz/en/ film/397408/a-radical-cut.

160 Jiras.

161 Altman, p. 119.

162 For instance, in the late 1970s, Bulgarian authorities accepted the concept of enforced assimilationism developed by Czech experts for practicing surveillance over Roma. Some of the Czech texts were translated in order to equip practitioners with advanced methods.

163 Sandra Harding (2006) Science and Social Inequality: Feminist and Postcolonial Issues, Urbana and Chicago, University of Illinois Press, p. 21.

164 Balibar and Wallerstein, p. 22.

165 Ibid, p. 23.

166 Altman, p. 263.

167 Ibid, p. 264.

1 Gabriele Griffin with Rosi Braidotti (2002) Whiteness and European Situatedness, in Gabriele Griffin and Rosi Braidotti (eds.) Thinking Differently: A Reader in European Women's Studies, London and New York, Zed Books, pp. 221-246, 227.

2 Etienne Balibar and Immanuel Wallerstein (1997) Race, Nation, Class: Les identites ambigues, Paris, La Decouverte, p. 19.

3 Nira Yuval Davis (1997) Gender and Nation, London, Sage, p. 53.

4 Colin Salter (2013) Whiteness and Social Change: Remnant Colonialisms and White Civility in Australia and Canada, Newcastle upon Tyne, UK, Cambridge Scholars Publishing.

5 Stephan Hopgood (2014) The End of Human Rights, Washington Post, available online at www.washingtonpost.com/opinions/the-end-of-human-rights/2014/01/03/7f8fa83c6742-11e3-ae56-22de072140a2_story.html.

6 Malcolm Langford (2018) Critiques of Human Rights, Annual Review of Law and Social Science, 14, pp. 69-89, 77.

7 Ibid, p. 70.

8 Marek Jakoubek and Lenka J. Budilová (2018) Fifty Years Researching Roma: Interview with Will Guy, Studia Ethnologica Pragensia, 1, pp. 147-163.

9 Langford, p. 75.

10 Roy Bhaskar (1991) Philosophy and the Idea of Freedom, Oxford, Blackwell.

11 Ibid.

12 Annabel Templett (2014) Making a Difference without Creating a Difference: SuperDiversity as a New Direction for Research on Roma Minorities, Ethnicities, 14, 6, pp. 830-848.

13 Etienne Balibar (2002) Politics and the Other Scene, London, Verso, p. 8.

14 Will Guy (1975[1998]) Ways of Looking at Roma: The Case of Czechoslovakia, in D. Tong (ed.) Gypsies: A Book of Interdisciplinary Readings, New York, Garland Publishing, Inc., pp. 13-48 [reprinted from F. Rehfisch (ed.) (1975) Gypsies, Tinkers and Other Travellers, London, Academic Press].

15 Davis, p. 54.

16 Ibid.

17 Sandra Harding (2006) Science and Social Inequality: Feminist and Postcolonial Issues, Urbana and Chicago, University of Illinois Press, p. 21.

18 Ibid.

19 Alexandra Oprea (2017) Towards the Recognition of Critical Race Theory in Human Rights Law: Roma Women's Reproductive Rights, in Jacqueline Bhabha, Andrzej Mirga et al. (eds.) Realizing Roma Rights, Philadelphia, University of Pennsylvania Press, pp. 39-57, 52.

20 Ibid, p. 56. 
21 Andrew Collier (1994) Critical Realism: An Introduction to Roy Bhaskar's Philosophy, London, Verso, p. 196.

22 Bhaskar.

23 Franz Baermann Steiner (1999) Orientpolitik, Value and Civilization, New York and Oxford, Berghahn Books, p. 16.

24 Sara Ahmed (2007) Phenomenology of Whiteness, Feminist Studies, 8, 2, pp. 149-168, 158.

25 Salter, p. 61.

26 Ondřej Slačálek (2016) The Postcolonial Hypothesis: Notes on the Czech "Central European" Identity, ALPPI Annual of Language \& Politics and Politics of Identity, 10, pp. $27-44$.

27 Sean Creaven (2002) The Pulse of Freedom? Bhaskar's Dialectic and Marxism, Historical Materialism, 10, 2, pp. 77-141, 80.

28 Salter, p. 31.

29 Rick Altman (2008) A Theory of Narrative, New York, Columbia University Press, p. 285 .

30 Hallvard Fossheim (2019) Past Responsibility: History and the Ethics of Research on Ethnic Groups, Studies in History and Philosophy of Biological and Biomedical Sciences, 73 , pp. 35-43, 42. 